\title{
Catharanthus terpenoid indole alkaloids: biosynthesis and regulation
}

\author{
Magdi El-Sayed $\cdot$ Rob Verpoorte
}

Received: 29 August 2005/ Accepted: 23 October 2006/Published online: 10 March 2007

(C) Springer Science+Business Media B.V. 2007
Abstract Catharanthus roseus is still the only source for the powerful antitumour drugs vin- blastine and vincristine. Some other pharmaceu- tical compounds from this plant, ajmalicine and serpentine are also of economical importance. Although $C$. roseus has been studied extensively and was subject of numerous publications, a full characterization of its alkaloid pathway is not yet achieved. Here we review some of the recent work done on this plant. Most of the work focussed on early steps of the pathway, particu- larly the discovery of the 2-C-methyl-D-erythritol 4-phosphate (MEP)-pathway leading to terpe- noids. Both mevalonate and MEP pathways are utilized by plants with apparent cross-talk be- tween them across different compartments. Many genes of the early steps in Catharanthus alkaloid pathway have been cloned and overexpressed to improve the biosynthesis. Research on the late steps in the pathway resulted in cloning of several genes. Enzymes and genes involved in indole alkaloid biosynthesis and various aspects of their
M. El-Sayed · R. Verpoorte ( $\square)$
Department of Pharmacognosy, Section of
Metabolomics, Institute of Biology Leiden, Leiden
University, Leiden, The Netherlands
e-mail: verpoort@chem.leidenuniv.nl
localization and regulation are discussed. Much progress has been made at alkaloid regulatory level. Feeding precursors, growth regulators treat- ments and metabolic engineering are good tools to increase productivity of terpenoid indole alka- loids. But still our knowledge of the late steps in the Catharanthus alkaloid pathway and the genes involved is limited.
Keywords Indole alkaloids · Biosynthesis · Catharanthus · Indole pathway - MEP pathway . Regulation · Terpenoids

$\begin{array}{ll}\text { Abbreviations } \\ \text { AACT } & \text { Acetoacetyl-CoA thiolase } \\ \text { ABA } & \text { Abscisic acid } \\ \text { AS } & \text { Anthranilate synthase } \\ \text { AVLB } & \text { Anhydrovinblastine } \\ \text { CMS } & \text { 4-Cytidyl diphospho-2 C-methyl-D- } \\ & \text { erythritol synthase } \\ \text { CPR } & \text { Cytochrome P450 reductase } \\ \text { CR } & \text { Cathenamine reductase } \\ \text { DAT } & \text { Acetyl CoA:deacetylvindoline 17- } \\ & \text { O-acetyltransferease } \\ \text { D4H } & \text { Desacetoxyvindoline 4-hydroxylase } \\ \text { DMAPP } & \begin{array}{l}\text { Dimethylallyl diphosphate } \\ \text { DXP }\end{array} \\ \text { 1-Deoxy-D-xylulose-5-phosphate } \\ \text { DXR } & \text { 1-Deoxy-D-xylulose-5-phosphate } \\ & \text { reducto isomerase } \\ \text { DXS } & \text { 1-Deoxy-D-xylulose-5-phosphate } \\ & \text { synthase }\end{array}$
M. El-Sayed
Department of Botany, Aswan Faculty of Science,
South Valley University, Aswan, Egypt 


$\begin{array}{ll}\text { GAP } & \text { Glyceraldehyde-3-phosphate } \\ \text { G10H } & \text { Geraniol 10-hydroxylase } \\ \text { GPP } & \text { Geranyl diphosphate } \\ \text { HMG-CoA } & \text { 3-Hydroxy-3-methylglutaryl-CoA } \\ \text { HMGS } & \text { 3-Hydroxy-3-methylglutaryl-CoA } \\ & \text { synthase } \\ \text { HMGR } & \text { 3-Hydroxy-3-methylglutaryl-CoA } \\ & \text { reductase } \\ \text { IPP } & \text { Isopentenyl diphosphate } \\ K_{\mathrm{m}} & \text { Michaelis-Menten constant } \\ \text { LAMT } & \text { Loganic acid methyltransferase } \\ \text { MCS } & \text { 2-C-Methyl-D-erythritol } \\ & \text { 2,4-cyclodiphosphate synthase } \\ \text { MEP } & \text { 2-C-methyl-D-erythritol } \\ & \text { 4-phosphate } \\ \text { MVAK } & \text { Mevalonate kinase } \\ \text { MJ } & \text { Methyljasmonates } \\ M_{\mathrm{r}} & \text { Relative molecular weight } \\ \text { MVA } & \text { Mevalonic acid } \\ \text { MVAPK } & \text { 5-Diphosphomevalonate kinase } \\ \text { NMT-SAM } & \text { Methoxy 2,16-dihydro-16- } \\ & \text { hydroxytabersonine } \\ \text { OMT } & N \text {-methyltransferase } \\ \text { ORCA } & \text { O-Methyltransferase } \\ \text { Octadecanoid-responsive } \\ \text { SAM } & \text { Catharanthus AP2/ERF-domain } \\ \text { SGD } & \text { S-Adenosyl-L-methionine } \\ \text { SLS } & \text { Strictosidine } \beta \text {-D-glucosidase } \\ \text { STR } & \text { Secologanin synthase } \\ \text { T16H } & \text { Strictosidine synthase } \\ \text { THAS } & \text { Tabersonine 16-hydroxylase } \\ \text { TIA } & \text { Tetrahydroalstonine synthase } \\ \text { TDC } & \text { Terpenoid indole alkaloids; } \\ & \text { Tryptophan decarboxylase } \\ & \\ & \\ & \end{array}$

HMG-CoA 3-Hydroxy-3-methylglutaryl-CoA
HMGS 3-Hydroxy-3-methylglutaryl-CoA

HMGR 3-Hydroxy-3-methylglutaryl-CoA

\section{Introduction}

Plant cells are considered to be excellent producers of a broad variety of chemical compounds. Many of these compounds are of high economic value such as various drugs, flavours, dyes, fragrances and insecticides. These compounds usually play a role in the interaction of the plant with its environment, e.g. as toxins to defend the plant against micro-organisms or various predators, as messengers, attractants, repellents or as camouflage (Verpoorte 1998).

Alkaloids are one of the largest classes of secondary metabolites. They contain a heterocyclic nitrogen usually with basic properties that makes them particularly pharmacologically active. Among them are the indole alkaloids which are found mainly in plants belonging to the families: Apocynaceae, Loganiaceae, Rubiaceae and Nyssaceae (Verpoorte et al. 1997).

Catharanthus roseus (L.) G. Don (Madagascar Periwinkle) is one of the most extensively investigated medicinal plants. The importance of this plant is due to the presence of two antitumour alkaloids, vinblastine and vincristine found in the leaves, and ajmalicine, an alkaloid found in the roots. All parts of this plant contain a variety of alkaloids, even seeds that were thought to have no alkaloids until Jossang et al. (1998) isolated two binsidole alkaloides from the seeds, vingramine and methylvingramine. Cell suspension cultures of $C$. roseus are an alternative means for the production of economically important terpenoid indole alkaloids (TIAs). However, the yields are too low to allow commercial application. The more than $100 \mathrm{C}$. roseus alkaloids that have been identified share many biosynthetic steps. The early stages of alkaloid biosynthesis in C. roseus involve the formation of secologanin derived from the terpenoid (isoprenoid) biosynthesis and its condensation with tryptamine to produce the central intermediate strictosidine, the common precursor for the monoterpenoid indole alkaloids (Fig. 1).

\section{The terpenoid pathway}

Terpenoids are the largest family of natural products with over 30,000 compounds. They are known to have many biological and physiological functions. Formation of terpenoids proceeds via two different pathways, the classical mevalonate and the newly discovered 2- $C$-methyl-D-erythritol 4-phosphate (MEP) pathway leading to isopentenyl diphosphate (IPP). In higher plants, the mevalonate pathway operates mainly in the cytoplasm and mitochondria. The MEP pathway operates in the plastids with a cross-talk between 


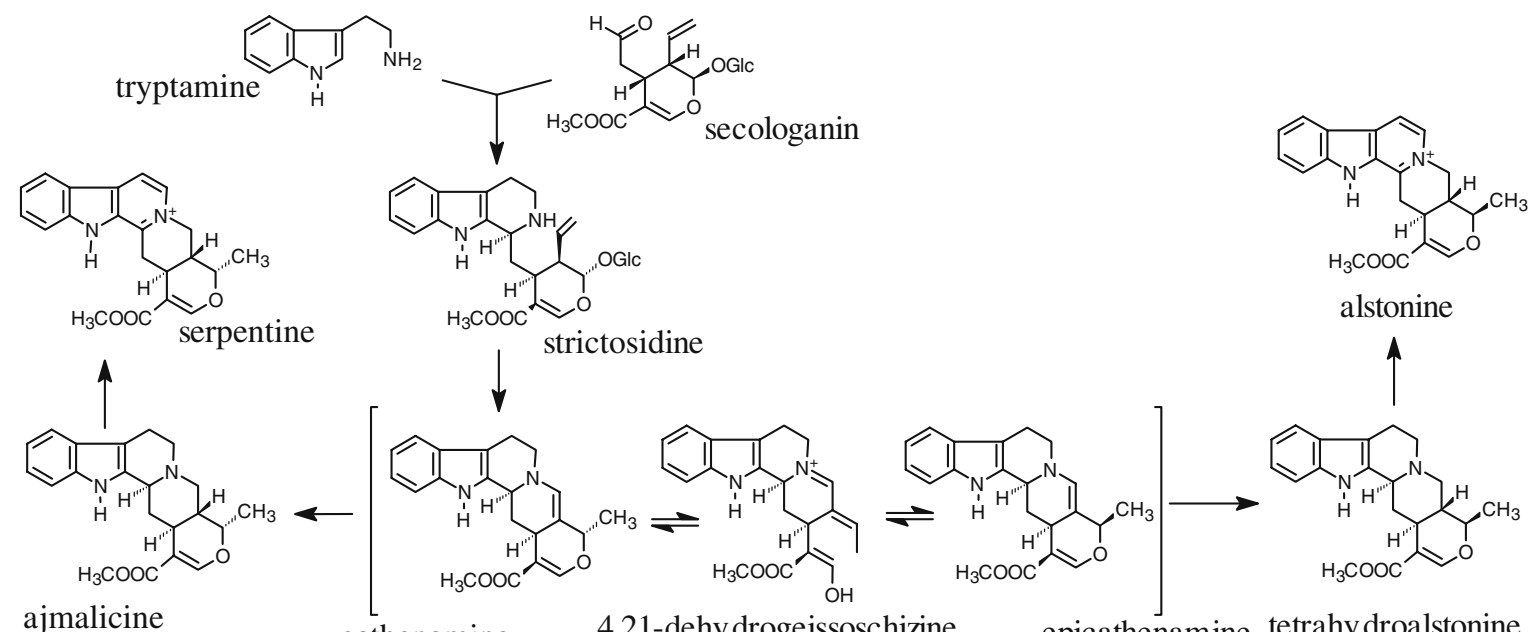

ajmalicine

$$
\text { cathenamine 4,21-dehy drogeissoschizine }
$$

epicathenamine tetrahydroalstonine

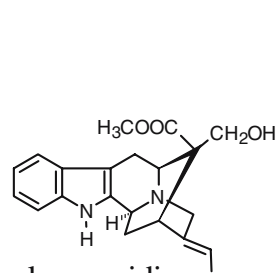

akuammidine

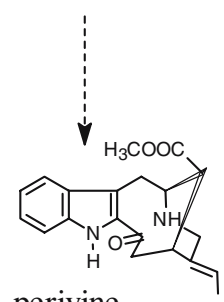

perivine

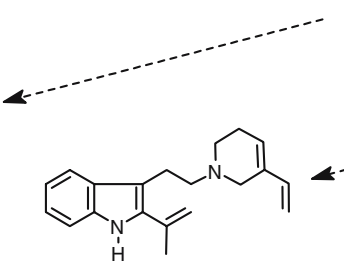

secodine

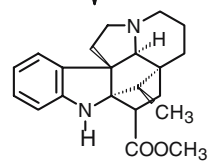

vindolinine

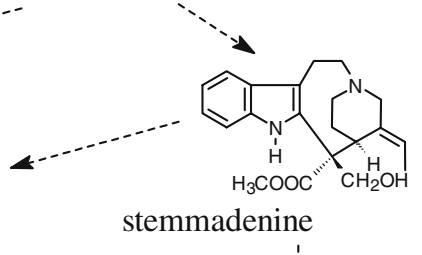

stemmadenine

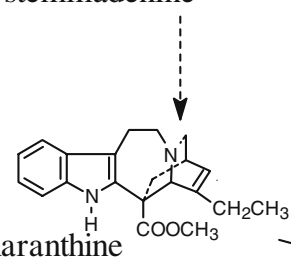

catharanthine

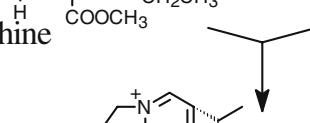

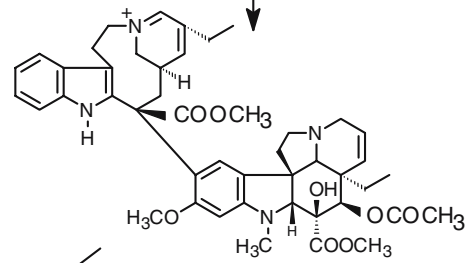
iminium

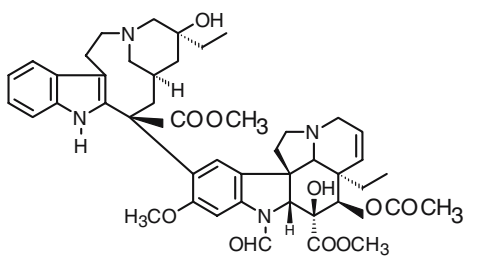

vincristine

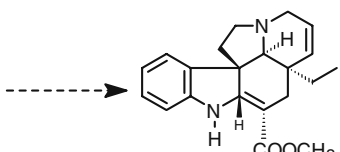

tabersonine

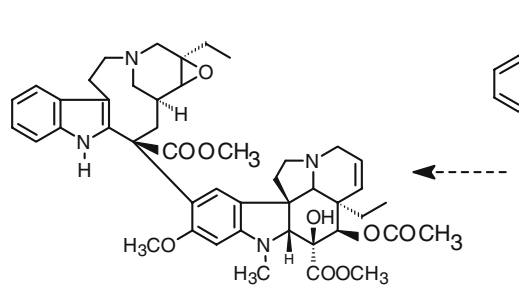

leurosine

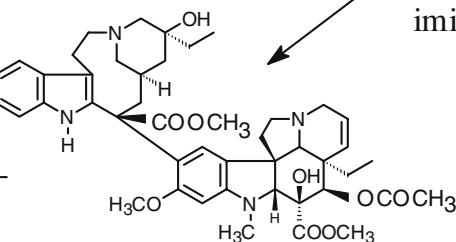

vinblastine

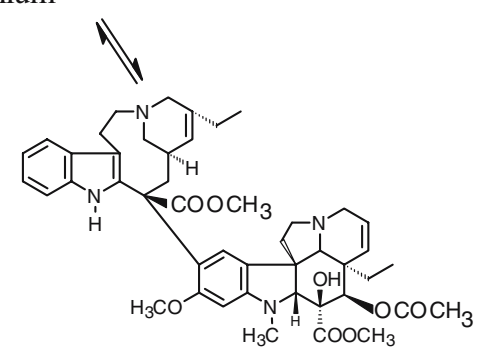

3',4'-anhy drovinblastine

Fig. 1 Different Catharanthus indole alkaloids biosynthetic pathways 
the two pathways where at least one metabolite can be exchanged.

\section{Formation of IPP}

The mevalonate pathway

The early steps in the isoprenoid pathway comprise the enzymatic conversions involved in the synthesis of IPP. The mevalonate pathway starts with the coupling of two molecules of acetyl-CoA to form acetoacetyl-CoA. This step is catalysed by the enzyme acetoacetyl-CoA thiolase (AACT). Condensation of acetoacetyl-CoA with another molecule of acetyl-CoA to form 3-hydroxy-3methylglutaryl-CoA (HMG-COA), is catalysed by HMG-CoA synthase (HMGS). Reduction of HMG-CoA by HMG-CoA reductase (HMGR) leads to the formation of mevalonate. Phosphorylation of mevalonate to 5-diphosphomevalonate is catalysed by mevalonate kinase (MVAK) and 5-diphosphomevalonate kinase (MVAPK), then 5-diphosphomevalonate is decarboxylated by 5diphosphomevalonate decarboxylase to IPP.

Isopentenyl diphosphate is considered as a building block of isoprenoids. The isomerization of IPP to form dimethylallyl diphosphate (DMAPP) is a key step in the biosynthesis of isoprenoids. This step is catalysed by IPP isomerase (E.C. 5.3.3.2; Ramos-Valdivia et al. 1997; Verpoorte et al. 1997). DMAPP is condensed with one IPP in a head-to-tail fashion generating geranyl diphosphate (GPP), the precursor for the monoterpenes including iridoids such as secologanin (Verpoorte et al. 1997; Contin 1999). The coupling reaction is catalysed by a prenyltransferase while the enzymatic cyclization of GPP is catalysed by a monoterpene synthase, GPP synthase (Chappell 1995).

The mevalonate-independent pathway leading to the formation of IPP (MEP pathway)

The biosynthesis of IPP, the central precursor of all isoprenoids, proceeds via two separate pathways in plants. The mevalonate pathway leads to the formation of triterpenes (sterols) and certain sesquiterpenes (Newman and Chappell 1999;
Lange and Croteau 1999). The second pathway is mevalonate-independent (MEP pathway) and leads to the formation of monoterpenes, diterpenes, tetraterpenes (carotenoids) and the prenyl side chains of chlorophyll (Eisenreich et al. 1996, 1997; Arigoni et al. 1997; Rohmer 1999).

The discovery of the MEP pathway for isoprenoid biosynthesis was reviewed by Rohmer (1999), Lichtenthaler (1999), Rohdich et al. (2001), Rodriguez-Concepcion and Boronat (2002) and Dubey et al. (2003). The pathway was first discovered in studies of the biosynthesis of bacterial hopanoids that are similar to sterols produced by eukaryotes and act as membrane stabilizers. As hopanoids are chemically stable and easily isolated, they are very suited for labelling experiments using stable isotopes followed by NMR to determine the sites of incorporation in the molecules. Through the labelling experiments, it was thought to be trivial to identify the isoprenoid units resulting from the mevalonic acid (MVA) route but, the pattern of the labels was completely different and did not fit the classical MVA pathway.

Sprenger (1996), in his labelling experiments on bacteria that utilize only hexoses, and especially glucose as a carbon source, determined the origin of isoprenic units of hopanoids as derived from glucose. The labelling pattern was in accordance with pyruvate as a precursor of a $\mathrm{C}_{2}$ subunit and a triose phosphate derivative as precursor of a $\mathrm{C}_{3}$ subunit.

For the MEP pathway, the biosynthetic sequence leading to the formation of IPP in plants is still not completely identified (Fig. 2). The complete pathway has been elucidated, including the late steps in bacteria (for review see Rodriguez-Concepcion and Boronat 2002).

The initial step of the pathway involves a condensation of pyruvate $\left(\mathrm{C}_{2}\right.$ and $\left.\mathrm{C}_{3}\right)$ with $\mathrm{D}$ glyceraldehyde 3-phosphate to yield 1-deoxy-Dxylulose-5-phosphate (DXP). Chahed et al. (2000) isolated and characterized the cDNA (crdxs) encoding for 1-deoxy-D-xylulose-5-phosphate synthase (DXS) from $C$. roseus. The enzyme that catalyses this reaction belongs to a family of transketolases. In the second step of this pathway, rearrangement and reduction of DXP to MEP takes place. The enzyme catalysing this step 
I. Mevalonate pathway

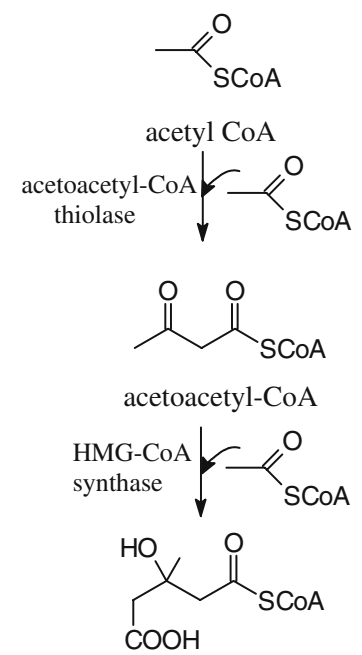

hydroxymethyl-glutaryl-CoA

\begin{tabular}{l|l}
$\mathrm{HMG}-\mathrm{CoA}$ \\
reductase
\end{tabular} \mid $\mathrm{NADPH}$<smiles>CC(O)(CC(=O)O)CC(=O)O</smiles>

mevalonate

MVA kinase $\downarrow$ ATP<smiles>CC(O)(CC(=O)[O-])CC(=O)O</smiles>

mevalonate phosphate MVAP kinase $\downarrow$ ATP<smiles>CC(O)(CC(=O)O)CC(=O)O[Na]</smiles>

mevalonate diphosphate

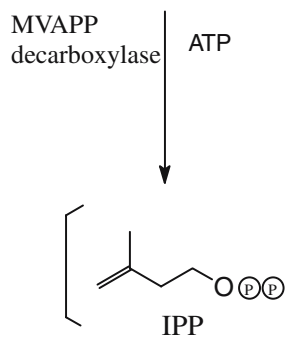

II. MEP pathway<smiles>CC(=O)C(=O)O</smiles>

pyruvate

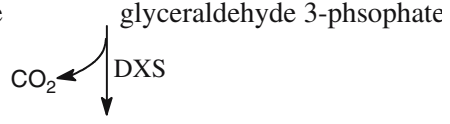<smiles>CC(=O)C(O)C(O)C[O-]</smiles>

1-deoxy-D-xylulose 5-phosphate

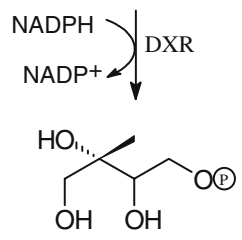

2-C-methyl-D-erythritol 4-phosphate
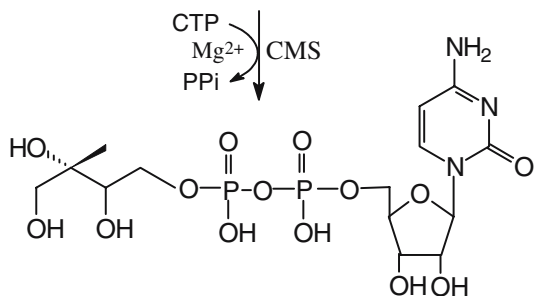

4-cytidyl diphospho-2 $C$-methyl-D-erythritol

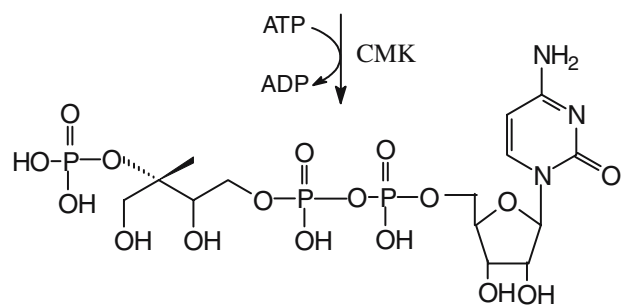

4-cytidyl diphospho-2C-methyl-D-erythritol 2-phosphate

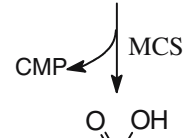<smiles>C[C@@]1(CO)OP(=O)(O)OP(=O)(O)OCC1O</smiles>

2-C-methyl-D-erythritol 2,4-cyclodiphosphate<smiles>CC(=O)OCC=C(C)CO</smiles>

1-hydroxy-2-methyl 2(E) butenyl 4 diphosphate

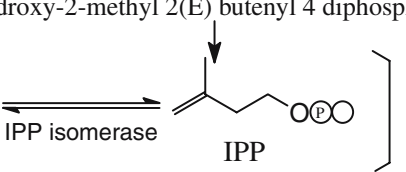

Fig. 2 The biosynthesis of IPP via mevalonate pathway and MEP pathway with involved enzymes 
is DXP reducto isomerase (DXR). Grolle et al. (2000) cloned the gene encoding this enzyme from the bacterium Zymomonas mobilis. Veau et al. (2000) reported the cloning and expression of cDNAs encoding crdxr and crmecs (reducto isomerase and 2-C-methyl-D-erythritol-2,4-cyclodiphosphate synthase) from $C$. roseus. The IPP is formed finally in low rate from isopentenyl monophosphate via a step catalysed by the enzyme isopentenyl monophosphate kinase. Contin et al. (1998) proved that the terpenoid moiety of the TIAs, secologanin is not derived from the mevalonate pathway but instead from the MEP pathway using a cell suspension culture of $C$. roseus. The late steps are not characterized yet in C. roseus. 4-Cytidyl diphospho-2 C-methylD-erythritol synthase was first cloned from Arabidopsis thaliana and expressed in Escherichia coli (Rohdich et al. 2000). Although there are few radiotracer studies in plants which demonstrated the possible phophorylation role of 4-diphosphocytidyl-2-C-methyl-D-erythritol kinase (CMK) in the pathway, the complete enzymology and its molecular analysis is not available in a plant system. The gene encoding 2-C-methyl-D-erythritol 2,4-cyclodiphosphate synthase has been demonstrated in Arabidopsis but the enzyme was not fully characterized.

The iridoid pathway

The first steps in the pathway leading to the formation of secologanin are the formation of geraniol followed by hydroxylation into 10 hydroxylgeraniol, catalysed by the cytochrome P450 enzyme geraniol 10-hydroxylase $(\mathrm{G} 10 \mathrm{H})$. In the presence of $\mathrm{NAD}^{+}$or $\mathrm{NADP}^{+}, 10$-hydroxygeraniol is oxidized into 10-oxogeranial. The enzyme responsible for this step is an oxido reductase (Madyastha and Coscia 1979). 10Oxogeraniol is converted to iridodial by cyclization. NADPH:cytochrome P450 reductase (CPR) is essential for the $\mathrm{G} 10 \mathrm{H}$ catalysed reaction. In the formation of 7-deoxyloganic acid from iridodial, so far, no enzymes have been described (Contin 1999). Methylation of loganic acid to form loganin is catalysed by $S$-adenosyl-Lmethionine:loganic acid methyltransferase (LAMT). Finally the cleavage of the cyclopentane ring of loganin forms the secologanin (Fig. 3). Conversion of loganin to secologanin is of particular interest, the enzyme catalysing this reaction is secologanin synthase (SLS). In C. roseus, Contin (1999) attempted to identify the enzyme involved in bioconversion of loganin to secologanin with no success. She reported that the conversion probably involves a cytochrome $\mathrm{P} 450$ enzyme. This enzyme was finally detected and characterized in a cell suspension culture of Lonicera japonica (Yamamoto et al. 2000). It is a membrane-associated enzyme belonging to the group of cytochrome P450 monooxygenases and its reaction requires NADPH and oxygen. Irmler et al. (2000) reported that the activities of CYP72A1 from C. roseus expressed in E. coli converts loganin into secologanin and confirmed it as SLS. This enzyme was previously purified from C. roseus by Mangold et al. (1994) and thought to have $\mathrm{G} 10 \mathrm{H}$ activity but did not show any hydroxylase activity with 11 substrates for cytochrome $\mathrm{P} 450$ reactions.

Characterized enzymes involved in the biosynthetic pathway leading to the formation of secologanin

\section{AACT (E.C. 2.3.1.9) and HMGS (E.C. 4.1.3.5)}

Both AACT and HMGS activities were found to be present in $C$. roseus by using an HPLC method specially developed to determine HMGCoA metabolizing enzyme activities. Using this method, three HMG-CoA catabolizing activities were discovered in $C$. roseus suspension cultured cells in addition to HMGR (Van der Heijden et al. 1994). These enzymes are instable and sensitive to high salt concentrations. AACT and HMGS were partially purified from a cell suspension culture of $C$. roseus (Van der Heijden and Verpoorte 1995).

\section{3-Hydroxy-3-methylglutaryl-CoA reductase (E.C. 1.1.1.34)}

The HMG reductase has been purified from a number of species besides $C$. roseus and its characteristics and regulation mechanisms have been the subject of extensive reviews (Chappell 


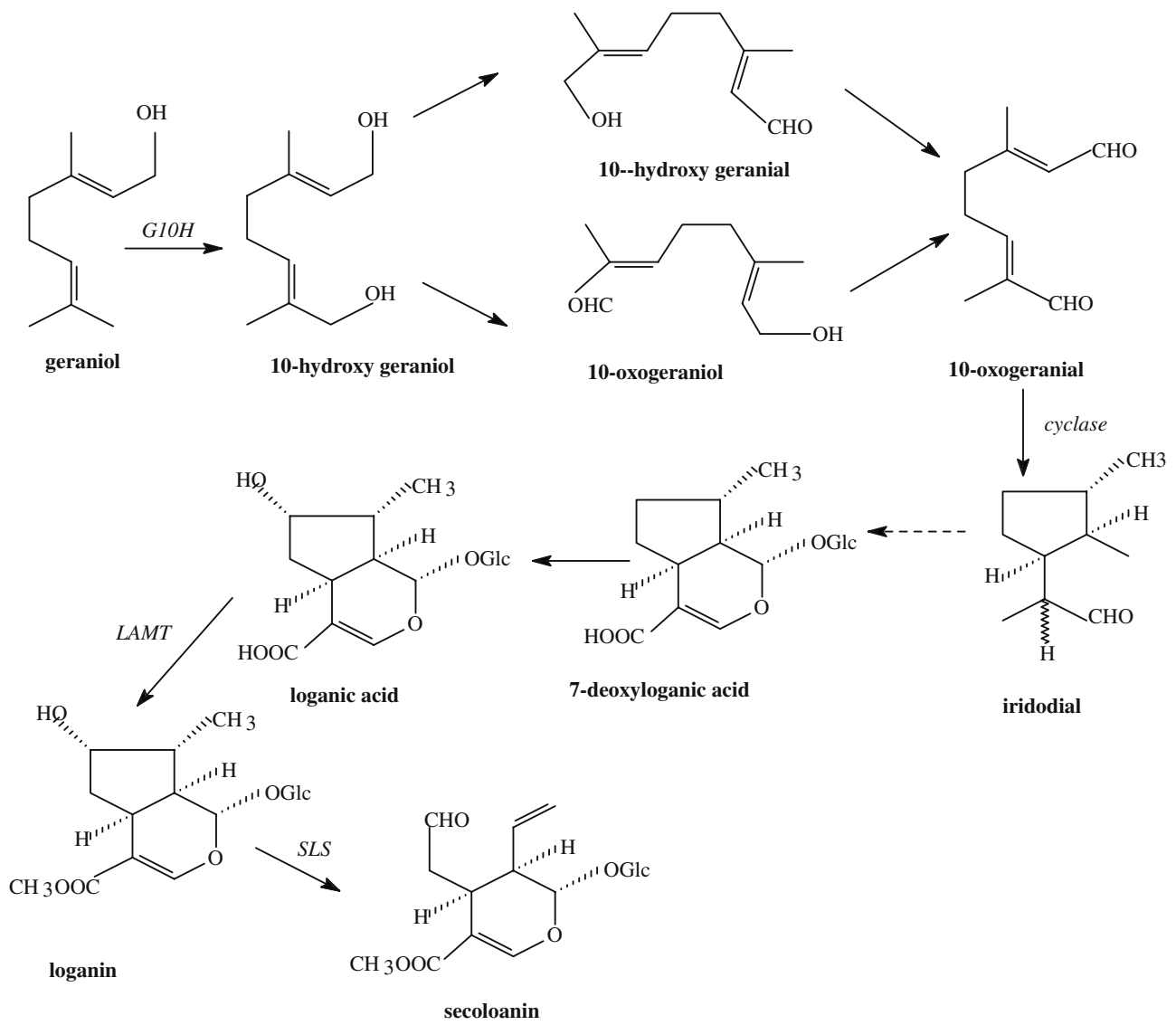

Fig. 3 The biosynthesis of secologanin from geraniol. $G 10 H$ geraniol 10-hydroxylase, LAMT loganic acid methyltransferase, $S L S$ secologanin synthase

1995; Bach 1995; Stermer et al. 1994; Verpoorte et al. 1997; Schulte 1998). Overexpression of the hmgr gene in C. roseus hairy roots resulted in an increase in alkaloid levels. A clone with high hybridization signal produced more ajmalicine and catharanthine than the control, whereas the clone with low hybridization signal increased the production of serpentine up to sevenfold (AyoraTalavera et al. 2002).

\section{$\operatorname{MVAK}($ E.C. 2.7.1.36) and MVAPK (E.C. 2.7.4.2)}

The phosphorylation of MVA to the mono- and di-phosphate ester (MVAP and MVAPP) has been extensively studied in $C$. roseus plants and cell cultures (Schulte 1998). MVAK from $C$. roseus cell cultures was purified to homogeneity and characterized. The enzyme showed to be quite stable. It is strongly inhibited by farnesyl diphosphate. MVAK activity depends on the presence of the divalent ions, $\mathrm{Mg}^{2+}$ and $\mathrm{Mn}^{2+}$ which are effective in sustaining the activity. It also has a broad $\mathrm{pH}$ optimum between 7 and 10 with a maximum activity around $\mathrm{pH} 9$ (Schulte et al. 2000). MVAPK from C. roseus was also purified and characterized (Schulte et al. 1999).

5-Diphosphomevalonate decarboxylase (MVAPP decarboxylase, E.C. 4.1.1.33)

The MVAPP decarboxylase that forms IPP from MVAPP has not yet been given much attention and has only been characterized in a few plant species (Verpoorte et al. 1997; Contin 1999). The formation of IPP was reviewed by Ramos-Valdivia et al. (1997). 
IPP isomerase (E.C. 5.3.3.2)

Isopentenyl diphosphate isomerase was partially purified from C. roseus cultures (Ramos-Valdivia et al. 1998). IPP-isomerase activity was also determined in 5-day-old C. roseus suspension cultured cells, treated with Pythium aphanidermatum elicitor preparation. A slight inhibition of the enzyme was observed during the first $120 \mathrm{~h}$ after elicitor treatment (Moreno et al. 1996).

\section{Geranyl diphosphate synthase (E.C. 5.1.1.1)}

The enzyme GPP synthase is not yet investigated in C. roseus (Contin 1999).

\section{Geraniol 10-hydroxylase}

This enzyme is a cytochrome $\mathrm{P} 450$ monooxygenase dependent on NADPH. G10H is regarded as a potential site for regulatory control in the biosynthesis of secologanin. Studies by Schiel et al. (1987) showed that G10H activity is induced when $C$. roseus cell cultures are transferred to an induction medium known to enhance alkaloid accumulation and that there is a close relationship between $\mathrm{G} 10 \mathrm{H}$ activity and alkaloid accumulation. Also McFarlane et al. (1975) demonstrated that $\mathrm{G} 10 \mathrm{H}$ is feedback inhibited by the TIAs catharanthine, vinblastine and vindoline. The $K_{\mathrm{i}}$ of catharanthine inhibition $(1 \mathrm{mM})$ is in the range of alkaloid concentration in C. roseus (0.3$1 \mathrm{mM}$ ). Madyastha et al. (1976) partially purified $\mathrm{G} 10 \mathrm{H}$ from $C$. roseus seedlings. Meijer et al. (1993a) purified $\mathrm{G} 10 \mathrm{H}$ from $C$. roseus suspension cultured cells in a four-step procedure after solublization with cholate. The protein showed a $M_{\mathrm{r}}$ of 56,000 and a $K_{\mathrm{m}}$ of $5.5 \mu \mathrm{M}$ geraniol and $11 \mu \mathrm{M}$ nerol. Also, Collu et al. (2001) purified this enzyme from $C$. roseus cell cultures following the method developed by Meijer et al. (1993a) with some modifications.

\section{NADPH:cytochrome $P 450$ reductase (E.C. 1.6.2.4)}

Cytochrome $\mathrm{P} 450$ reductase functions in electron transfer from NADPH and is essential for all cytochrome P450 monooxygenases. It was puri- fied from C. roseus plants (Madyastha and Coscia 1979) and from cell cultures (Meijer et al. 1993b). The protein showed a $M_{\mathrm{r}}$ of 79,000 and the activity is dependent on NADPH, FAD and FMN as cofactors. In $C$. roseus the CPR mRNA level is enhanced by fungal elicitor treatments (Meijer et al. 1993a, b, Lopes Cardoso et al.,1997). Like the yeast and animal CPRs, C. roseus protein contains a hydrophobic domain close to the $\mathrm{N}$-terminus which serves as a membrane anchor. Steady-state mRNA levels observed in C. roseus plants were higher in flowers and much lower in leaves and stems while intermediate in the roots.

\section{Cyclase}

The dialdehyde (10-oxogeranial/10-oxoneral) is cyclized to iridodial. The enzyme responsible for the cyclization has not yet been purified from $C$. roseus but was obtained from Rauwolfia serpentina (Uesato et al. 1986, 1987; Verpoorte et al. 1997).

\section{Loganic acid methyltransferase (E.C. 2.1.1.50)}

In the formation of 7-deoxyloganic acid from iridodial, so far no enzymes have been described (Contin 1999). The 7-hydroxylation to afford loganic acid must precede its methylation, as suggested by enzymatic studies with the $S$-adenosyl-L-methionine:LAMT partially purified from C. roseus seedlings (Madyastha et al. 1973). This enzyme catalyses the transfer of a methyl group to loganic acid to form loganin. Contin (1999) measured the activity of LAMT in C. roseus cells cultured on three different media and found that the activity is restricted to the early period of growth similarly to the results obtained by Guarnaccia et al. (1974) and Madyastha and Coscia (1979) in C. roseus seedlings where maximum activity of the enzyme was recorded just after germination.

\section{Secologanin synthase (E.C. 1.3.3.9)}

Secologanin synthase belongs also to the cytochrome P450 family. This gene was cloned 12 years ago from $C$. roseus and was first thought to encode G10H (Vetter et al. 1992) but recently it 
was shown that it encodes the enzyme that converts loganin to secologanin (Irmler et al. 2000). This cytochrome P450 enzyme accepts only loganin as substrate with an optimum catalysing reaction at a $\mathrm{pH}$ of 7.5 (Yamamoto et al. 2000).

Enzymes involved in the MEP pathway

leading to the formation of IPP

\section{1-Deoxy-D-xylulose 5-phosphate synthase (E.C.} 4.1.3.37)

Bacteria, fungi, yeasts and plants are capable of synthesizing 1-deoxy-D-xylulose (DX) or its 5-phosphate (DXP) from pyruvate and from D-glyceraldehyde or from its phosphate (GAP). The enzymatic activity in this step is thiamine diphosphate dependent and probably related to pyruvate dehydrogenase. As the reaction is not specific, the system can accept acyloins in place of pyruvate as acetyl donor and also different aldoses, yielding 1-deoxyketoses with $\mathrm{C}_{5}, \mathrm{C}_{6}$ or $\mathrm{C}_{7}$ skeletons.

The enzyme catalyses the concomitant decarboxylation of pyruvate and the condensation of the resulting (hydroxyethyl) thiamine on free GAP, yielding deoxyxylulose or its phosphate (DXP). As free glyceraldehyde is not a usual cellular metabolite, GAP and DXP are thought to be the normal substrate and product of the synthase.

\section{1-Deoxy-D-xylulose 5-phosphate reducto isomerase (E.C. 1.1.1.267)}

The rearrangement of DX or DXP yields 2- $C$ methyl-D-erythrose or its 4-phosphate and the reduction of these products yields 2- $C$-methyl-Derythritol (ME) or its 4-phosphate (MEP; Duvold et al. 1997a,b, Sagner et al. 1998).

Using E. coli mutants that were auxotrophic to $\mathrm{ME}$, a gene that complemented in these mutants the region coding for IPP biosynthesis was cloned and led to the identification of the enzyme responsible for the conversion of DXP into MEP (Takahashi et al. 1998). This reductoisomerase enzyme is NADPH-dependent and requires $\mathrm{Mn}^{2+}$ as cofactor. It catalyses two consecutive steps: the rearrangement of DXP into
2-C-methyl-D-erythrose and the reduction of this aldose to MEP. The free aldose phosphate was not detected and the presence of the 5-phosphate group on DXP was required for the enzymatic conversion.

Isopentenyl monophosphate kinase (E.C. 2.7.1.)

Lange and Croteau (1999) reported the cloning of the gene encoding IPK from peppermint and $E$. coli. This kinase catalyses the phosphorylation of isopentenyl monophosphate as the last step of the biosynthetic sequence to IPP. This enzyme belongs to a conserved class of the GHMP family of kinases that includes galactokinase, homoserine kinase, MVAK and phosphomevalonate kinase. This enzyme was thought to catalyse the last step in the MEP pathway, however Rohdich et al. (2000) showed that the overexpressed CMK protein from tomato does not have any IPK activity, even if very high concentrations of recombinant enzyme were used. The detected IPK activity could not be metabolically relevant and cannot confirm the final steps leading to IPP synthesis.

\section{Localization of the enzymes involved in the pathways leading to the formation of secologanin}

In the mevalonate pathway, the enzymes are localized in the cytosol and produce the precursor of triterpenes and sesquiterpenes. Nothing has been reported on the localization of AACT/ HMGS enzymes in $C$. roseus although they were purified from a cell suspension cultures (Van der Heijden et al. 1994; Van der Heijden and Verpoorte 1995). The radish AACT and HMGS have been reported as membrane-associated enzymes (Weber and Bach 1994; Bach et al. 1994). It has been suggested that HMGR might be located in mitochondria and plastids of plants (Gary 1987; Stermer et al. 1994). The regulated degradation of HMGR has been indicated to be completely localized in the endoplasmic reticulum in yeast (Hampton and Rine 1994). Evidence that HMGR is located within endoplasmic reticulum as well as in spherical, vesicular structures 
derived from endoplasmic reticulum has been recently given (Leivar et al. 2005).

The plant enzymes MVAK and MVAPK were presumed to be predominantly cytosolic but have been proven to be present in plastids as well (McKaskill and Croteau 1995; Albrecht and Sandmann 1994). The subcellular localization of MVAK and MVAPK was studied in suspension cultured cells of $C$. roseus and it was shown that most of the activity of both enzymes was located in the cytosolic fraction. MVAK activity was also recovered from an organellar and microsomal fraction. MVAPK activity was detected in the organelle fraction (Schulte et al. 1999, 2000).

The localization of IPP isomerase in C. roseus has not been determined yet but in Castor beans, a mitochondrial and proplastidial IPP isomerase have been detected (Green et al. 1975). In glandular trichomes of peppermint, it was found that the cytoplasmic MVA pathway was blocked at the level of HMGR and that the IPP utilized for both plastidial monoterpene and cytosolic sesquiterpene biosynthesis is synthesized exclusively in the plastids. A connection of the pathway was proposed at the level of IPP that requires translocation of IPP to the different compartments and the presence of an isoform of IPP isomerase in each compartment (McKaskill and Croteau 1995). Ramos-Valdivia et al. (1997) extensively reviewed the IPP isomerase.

In Lithospermum erythrorhizon, the enzyme GPP synthase involved in the biosynthesis of naphthoquinones was found to be present in the cytosol (Sommer et al. 1995).

The enzyme $\mathrm{G} 10 \mathrm{H}$ is associated with (pro)vacuolar membranes (Madyastha et al. 1977) rather than with endoplasmic reticulum where many P450s are found (Nebert 1979). Collu (1999), studied the localization of $\mathrm{G} 10 \mathrm{H}$ in $C$. roseus cell suspension cultures and confirmed that this enzyme is localized in vacuolar membranes. The CPR catalysing cytochrome P450 monooxygenase reactions is a membrane-bound flavoprotein, closely linked to the $\mathrm{P} 450$ protein. The expression of the three identified $C$. roseus MEP pathway genes and the $\mathrm{G} 10 \mathrm{H}$ genes was found to be in internal phloem parenchyma, i.e. in cells different than the other known alkaloid biosynthesis related genes (Burlat et al. 2004).

\section{Localization of the non-mevalonate pathway leading to the formation of IPP}

The biosynthesis of mono-, di- and tetraterpenoids in plants seems to occur in plastids, where the MEP pathway is localized (Rohmer 1999; Lange and Croteau 1999). In plastids, the DXP pathway operates to supply IPP for the synthesis of monoterpenes, diterpenes and carotenoids. Table 1 summarizes the information about the known enzymes involved in TIA biosynthesis in C. roseus.

\section{Genes-encoding enzymes involved in the biosynthesis of secologanin}

A cDNA clone for radish AACT has been cloned by complementation in yeast (Vollack and Bach 1995). Using the radish cDNA as a probe to screen an $A$. thaliana cDNA library, four positive clones have been isolated of which three were identical and the fourth shown to be an antisense (Piñas et al. 1997). The presence of antisense mRNA could indicate a regulatory mechanism of controlling translation of AACT mRNA.

A cDNA encoding the $A$. thaliana HMGS has been cloned (Montamat et al. 1995) and expressed in E. coli (Diez et al. 1997). In addition to the $A$. thaliana HMGS gene, also the HMGS gene has been cloned from Schizosaccharomyces pombe (Katayama et al. 1995).

Plants have a small gene-family of HMGR isoenzymes that are differentially expressed and respond to a variety of developmental and environmental signals (Stermer et al. 1994; Enjuto et al. 1994; Weissenborn et al. 1995; Korth et al. 1997). HMGR genes have been well studied in Solanaceae species. Four HMGR genes have been isolated from tomato. One of them, the hmg1 gene has been found to be involved in aspects related to primary metabolism like sterol biosynthesis and cell growth. The activation pattern of the second HMGR gene hmg2 by wounding and elicitation has suggested a role in the plant's defence (Weissenborn et al. 1995). Also potato, has at least three HMGR genes (Stermer et al. 1994). A C. roseus hmg cDNA has been cloned (Maldonada-Mendosa et al. 1992). In C. roseus cell suspensions, methyl jasmonate has been 
Table 1 Enzymes involved in biosynthesis of indole alkaloids of C. roseus

\begin{tabular}{|c|c|c|c|c|}
\hline Enzyme & Abbreviation & Cofactors & Product & Localization \\
\hline Anthranilate synthase & AS & $\mathrm{Mg}^{2+}$ & Anthranilate & Plastid \\
\hline Tryptophan decarboxylase & TDC & $\mathrm{PP}, \mathrm{PQQ}$ & Tryptamine & Cytosol \\
\hline $\begin{array}{l}\text { Isopentenyl diphosphate } \\
\text { isomerase }\end{array}$ & $\begin{array}{l}\text { IPP } \\
\text { isomerase }\end{array}$ & $\mathrm{Mg}^{2+}, \mathrm{Mn}^{2+}$ & $\begin{array}{l}\text { 3,3-Dimethylallyl } \\
\text { diphosphate }\end{array}$ & Plastid \\
\hline Geraniol 10-hydroxylase & $\mathrm{G} 10 \mathrm{H}$ & Haeme & 10-Hydroxygeraniol & $\begin{array}{l}\text { Provacuolar } \\
\text { membrane }\end{array}$ \\
\hline $\begin{array}{l}\text { NAPDH:cytochrome } \\
\text { P450 reductase }\end{array}$ & CPR & $\begin{array}{l}\text { NADPH, } \\
\text { FAD, } \\
\text { FMN }\end{array}$ & - & $\begin{array}{l}\text { Provacuolar } \\
\text { membrane }\end{array}$ \\
\hline $\begin{array}{l}\text { SAM:loganic acid } \\
\text { methyltransferease }\end{array}$ & LAMT & SAM & Loganin & - \\
\hline Secologanin synthase & SLS & NADPH & Secologanin & - \\
\hline Strictosidine synthase & STR & - & Strictosidine & Vacuole \\
\hline Strictosidine $\beta$-glucosidase & SGD & - & [Cathenamine] & $\begin{array}{l}\text { Endoplasmic } \\
\text { reticulum }\end{array}$ \\
\hline Cathenamine reductase & $\mathrm{CR}$ & NADPH & Ajmalicine & - \\
\hline Geissoschizine dehydrogenase & - & $\mathrm{NADP}^{+}$ & $\begin{array}{l}\text { 4,21-Dehydrogeis- } \\
\text { soschizine }\end{array}$ & - \\
\hline Tetrahydroalstonine synthase & THAS & NADPH & Tetrahydroalstonine & - \\
\hline Tabersonine 16-hydroxylase & $\mathrm{T} 16 \mathrm{H}$ & $\begin{array}{l}\text { Haeme, } \\
\text { NADPH }\end{array}$ & 16-Hydroxytabersonine & $\begin{array}{l}\text { Endoplasmic } \\
\text { reticulum }\end{array}$ \\
\hline $\begin{array}{l}\text { 11-Hydroxytabersonine } \\
O \text {-methyltransferase }\end{array}$ & OMT & - & 16-Methoxytabersonine & - \\
\hline $\begin{array}{l}\text { SAM:methoxy } 2,16 \text {-dihydro-16- } \\
\text { hydroxytabersonine } \\
N \text {-methyltransferase }\end{array}$ & NMT & SAM & Desacetoxyvindoline & $\begin{array}{l}\text { Thylakoid } \\
\text { membranes }\end{array}$ \\
\hline $\begin{array}{l}\text { Desacetoxyvindoline } \\
\text { 17-hydroxylase }\end{array}$ & $\mathrm{D} 4 \mathrm{H}$ & $2-$ & $\begin{array}{l}\text { Oxoglutarate, } \\
\mathrm{Fe}^{2+} \text {, ascorbate }\end{array}$ & Desacetylvindoline \\
\hline \multicolumn{5}{|l|}{ Cytoplasm } \\
\hline $\begin{array}{l}\text { Acetyl CoA:deacetylvindoline } \\
17-O \text {-acetyltransferase }\end{array}$ & DAT & Acetyl CoA & Vindoline & Cytoplasm \\
\hline $\begin{array}{l}\text { Acetyl CoA:minovincinine- } O \text { - } \\
\text { acetyltransferase }\end{array}$ & MAT & Acetyl CoA & Echitovenine & Cytoplasm \\
\hline Anhydrovinblastine synthase & $\begin{array}{l}\text { AVLB } \\
\text { synthase }\end{array}$ & - & Anhydrovinblastine & Vacuole \\
\hline
\end{tabular}

shown to be able to increase HMGR mRNA levels after a transient suppression (MaldonadaMendosa et al. 1994).

The gene of deoxyxylulose 5-phosphate synthase has been isolated from E. coli (Sprenger et al. 1997; Lois et al. 1998) and cloned from higher plants, Mentha $\times$ piperita (Lange et al. 1998) and C. roseus (Chahed et al. 2000; Veau et al. 2000). The gene encoding the DXR enzyme was cloned from higher plants such as peppermint (Lange and Croteau 1999), A. thaliana (Lange and Croteau 1999; Schwender et al. 1999) and $C$. roseus (Veau et al. 2000).

Molecular cloning of $\mathrm{G} 10 \mathrm{H}$ has been previously attempted using several different approaches. Differential screening of a $C$. roseus cDNA library resulted in the isolation of two highly homologous cytochrome P450 cDNAs and their corresponding mRNAs were induced in alkaloid production when compared to normal growth medium (Vetter et al. 1992). Measuring the expression of the gene in different parts of the plant showed that mRNA levels were highest in the flowers. Attempts to clone the $\mathrm{G} 10 \mathrm{H}$ gene by immunoscreening of a $C$. roseus cDNA library were not successful because the antibodies raised against the purified $\mathrm{G} 10 \mathrm{H}$ protein were not sufficiently specific (Meijer et al. 1993a). Multiple cDNAs encoding P450s from $A$. thaliana were isolated by employing a PCR strategy with degenerate oligonucleotide primers designed on amino acid sequences conserved between plant cytochrome P450s (Mizutani et al. 1998). The gene was cloned by Collu et al. (2001) and expressed in C. roseus and yeast cells. It is 
strongly induced by methyljasmonate (MJ). Transgenic $C$. roseus cells showed that $\mathrm{G} 10 \mathrm{H}$ activity is correlated to the ability of the cells to accumulate TIAs, although the increased $\mathrm{G} 10 \mathrm{H}$ is not the only requirement for increased alkaloid accumulation (Collu et al. 2002). This gene was classified as a new member of the CYP76B plant P450 family.

Cytochrome $\mathrm{P} 450$ reductase is cloned from $C$. roseus cell cultures by Meijer et al. (1993b). Immunoscreening of a $C$. roseus cDNA expression library resulted in the isolation of a partial NADPH:CPR clone. The clone was identified on the basis of sequence homology with CPRs from yeast and animals. The gene is encoded by a single copy and the protein consists of 714 amino acids.

The indole pathway

\section{Biosynthesis of tryptophan}

Tryptophan is an aromatic amino acid derived from chorismate via anthranilate. Chorismate originates from the shikimate pathway (Fig. 4).

L-Tryptophan is formed through a biosynthetic pathway consisting of five enzymatically controlled steps (Poulsen and Verpoorte 1991; Verpoorte et al. 1997; Bongaerts 1998; Whitmer 1999). The first step is formation of anthranilate from chorismate. This step is catalysed by the enzyme anthranilate synthase (AS, E.C. 4.1.3.27). The second step is formation of $\mathrm{N}$-(5-phosphoribosyl) anthranilate and this step is catalysed by the enzyme phosphoribosyl diphosphate (PR)anthranilate transferase (E.C. 4.1.1.48). The third step is formation of 1-( $O$-carboxyphenylamino)1-deoxyribulose phosphate. This step is catalysed by the enzyme PR-anthranilate isomerase (E.C. 5.3.1.24). The following step is formation of indole-3-glycerol phosphate. This step is catalysed by the enzyme indole-3-glycerol phosphate synthase (E.C. 4.1.1.48). The next step is formation of indole which is catalysed by the enzyme tryptophan synthase $\alpha$ (E.C. 4.2.1.20). The last step is formation of L-tryptophan which is catalysed by the enzyme tryptophan synthase $\beta$ (E.C. 4.2.1.20). This enzyme was detected in the proteomics approach as being induced when alkaloid production is induced (Jacobs et al. 2005).

Enzymes involved in the biosynthesis of L-Tryptophan

Anthranilate synthase (E.C. 4.13.27)

Anthranilate synthase was first isolated and purified to apparent homogeneity from C. roseus

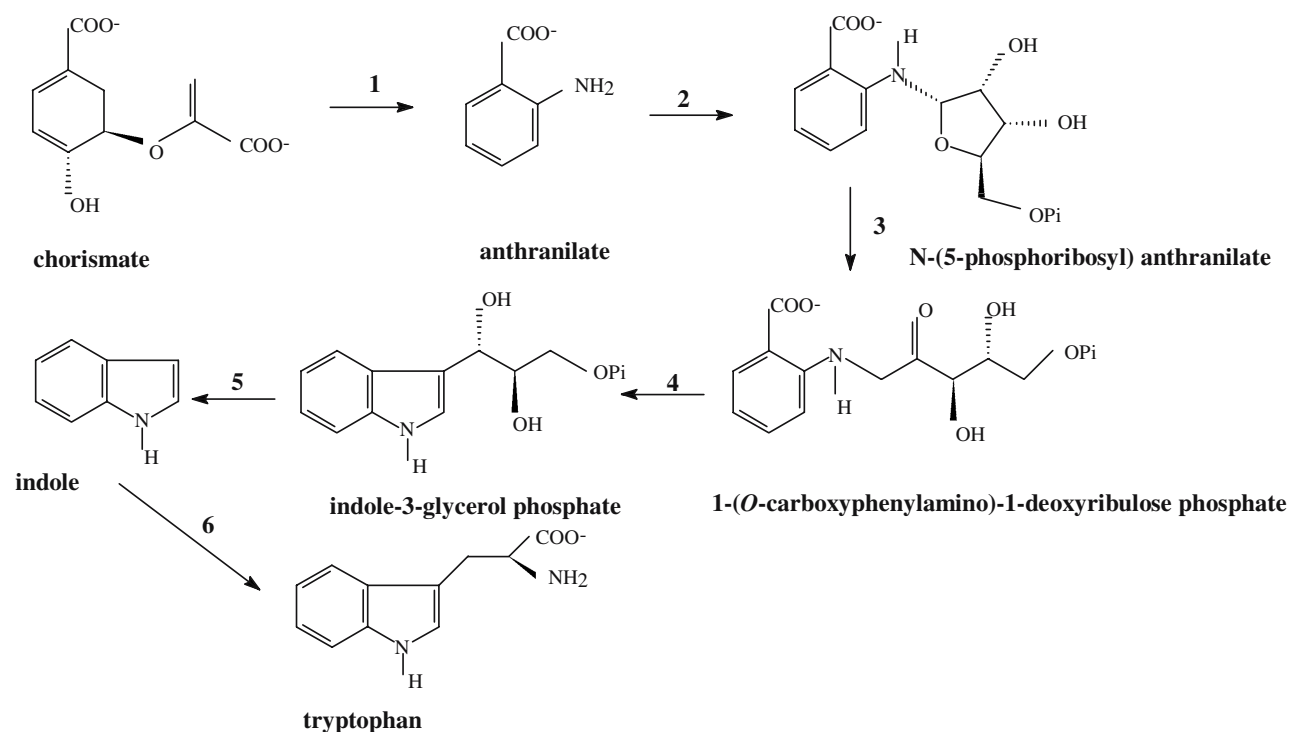

Fig. 4 Biosynthesis of L-tryptophan through the chorismate pathway. 1 anthranilate synthase, 2 phosphoribosyl diphosphate (PR) anthranilate transferase, 3 PR-anthra- nilate isomerase, 4 indole-3-glycerol phosphate synthase, 5 tryptophan synthase $\alpha, 6$ tryptophan synthase $\beta$ 
(Poulsen et al. 1993). It is a tetramer, consisting of two large and two small subunits. The large $\alpha$-subunit is responsible for the conversion of chorismate into anthranilate while the smaller $\beta$-subunits are responsible for the generation of the substrate $\mathrm{NH}_{3}$ from glutamine (Verpoorte et al. 1997). So far, none of the enzymes leading to tryptophan after AS has been studied in C. roseus (Moreno et al. 1995; Verpoorte et al. 1997).

Only a time course of tryptophan synthase (E.C. 4.2.1.20) activity during the growth of suspension cultured and immobilized cells of C. roseus has been determined (Facchini and DiCosmo 1991). Lower tryptophan synthase activity was present in immobilized cells than in suspension cultured cells. Using a proteomics approach, Jacobs (Jacobs 2003; Jacobs et al. 2005) identified the $\beta$-subunit tryptophan synthase in C. roseus cell suspension cultures which was detected during a short time of growth period and seemed to be correlated with alkaloid production.

Bongaerts (1998) reported the isolation and characterization of a full-length $C$. roseus cDNA encoding a functional AS $\alpha$ subunit. He found that AS activity is highest in roots compared with other organs of $C$. roseus and correlated well with the abundance of AS $\alpha$ transcripts in this organ. Expressing an AS $\alpha$ subunit insensitive to ajmalicine feedback in $C$. roseus hairy roots increases the production of tryptophan, tryptamine and lochnericine (Hughes et al. 2004a, b).

\section{Biosynthesis of tryptamine}

\section{Tryptophan decarboxylase (E.C. 4.1.1.28)}

Tryptamine is derived from primary metabolism by a single enzymatic conversion of the amino acid L-tryptophan, catalysed by tryptophan decarboxylase (TDC, E.C. 4.1.1.28). This enzyme was purified first by Noe and Berlin (1984), later this protein was extensively characterized (Fernandez et al. 1989; Pennings et al. 1989a, b). The enzyme is a soluble protein consisting of two identical subunits containing two molecules of pyridoxal phosphate (Pennings et al. 1989a). It was observed that TDC activity can be induced when suspension cultures of $C$. roseus are transferred from growth medium to alkaloid induction medium that contains a high concentration of sugar and low levels of hormones, nitrogen and phosphate (Knobloch et al. 1981). This enzyme is located on the interface between primary and secondary metabolism. It is considered a putative site for regulatory control of TIAs. However, generally there is no clear correlation between TDC activity and TIA biosynthesis in cell cultures of C. roseus (Knobloch and Berlin 1983; Merillon et al. 1986; Eilert et al. 1987; Facchini and DiCosmo 1991; Whitmer 1999).

Localization of TDC was shown to be in the cytosol (De Luca and Cutler 1987; Stevens et al. 1993). The expression of the $t d c$ gene was restricted to the upper epidermis of cotyledons in C. roseus (Vasquez-Flota et al. 2000).

Tryptophan decarboxylase cDNA has been cloned from $C$. roseus (De Luca et al. 1989). The $t d c$ gene was found to occur as a single copy in the C. roseus genome (Goddijn 1992). Expression of $t d c$ appeared to be highly regulated at the transcriptional level. In cell suspension cultures $t d c$ mRNA levels were shown to be downregulated by auxins and induced by fungal elicitors (Goddijn et al. 1992; Pasquali et al. 1992). The specific mRNAs encoding TDC enzyme activity, appear to be present in low quantities in developing seedlings if compared with the high levels of transcripts that occur in elicitor-induced cell suspension cultures of $C$. roseus by the fungus $P$. aphanidermatum. When $t d c$ upstream sequences from $-1,818$ to +198 relative to the transcriptional start site were analysed to identify cis-acting elements that determine basal expression or respond to elicitor, it was found that there were three functional regions in the -160 promoter. The region between -160 and -99 was shown to act as the main transcriptional enhancer while the other two elements (between -99 to -87 and between -87 to -37 ) were found to be not redundant in the $t d c$ promoter (Ouwerkerk and Memelink 1999). As TDC seems to represent an important site for regulatory control of alkaloid production, it was examined whether overexpression of $t d c$ affects alkaloid accumulation (Goddijn 1992). The TDC cDNA driven by the strong Cauliflower Mosaic Virus 35S promoter was introduced into $C$. roseus by means of an oncogenic Agrobacterium tumefaciens strain. Overexpression 
appeared not to result in an increased alkaloid accumulation but only enhanced tryptamine levels (Goddijn et al. 1995; Verpoorte et al. 1998). Expressing $t d c$ cDNA from C. roseus in a Nicotiana tabacum cell suspension culture (Hallard et al. 1997), resulted in the formation of tryptamine (about $10 \mu \mathrm{g} / \mathrm{g}$ fresh weight). This level of tryptamine is similar to that found in leaves of $t d c$ transgenic tobacco plants (ranging from 18 to $66 \mu \mathrm{g} / \mathrm{g}$ FW, Lopes Cardoso 1995).

\section{Biosynthesis of strictosidine}

Strictosidine is the central intermediate in the biosynthesis of many alkaloids. It is formed by coupling of the iridoid glycoside secologanin and tryptamine. The enzyme condensing both secologanin and tryptamine is strictosidine synthase (STR, E.C. 4.3.3.2, Stöckigt 1980; Pennings et al. 1989c; Kutchan 1993; Verpoorte et al. 1997).

\section{Strictosidine synthase (E.C. 4.3.3.2)}

The purification of STR from C. roseus was first described by Treimer and Zenk (1979) and Mizukami et al. (1979) with an estimated molecular weight between 34 and $38 \mathrm{kDa}$. There are seven STR isoforms of which four were characterized by Zenk's group. Those four isoforms differ in $\mathrm{p} I$ (4.34.8) and $K_{\mathrm{m}}$ value for tryptamine (from 0.9 to $6.6 \mathrm{mM}$ ) where the activity was inhibited at high levels. Also, De Waal et al. (1995), purified and characterized this enzyme from $C$. roseus cell suspension cultures. In that study, four out of six isoforms were purified to homogeneity while two others were nearly homogeneous. The isoforms have a broad $\mathrm{pH}$ range (6-7.5) and all of them have similar kinetics. No inhibition could be observed for up to $5 \mathrm{mM}$ tryptamine. The $K_{\mathrm{m}}$ value determined for all isoforms is around 8.2-9.4 which is higher than that reported by Zenk's group.

Recently, Jacobs (2003) and Jacobs et al. (2005) detected seven isoforms of STR in C. roseus cell suspension cultures by western blotting and twodimensional electrophoresis. Expression of those isoforms varies upon elicitation with $P$. aphanidermatum.

Strictosidine synthase activity could not be inhibited by the end product alkaloids: vindoline, catharanthine and ajmalicine (Mizukami et al. 1979).

Early studies on localization of STR indicated that it is a cytosolic protein (Deus-Neumann and Zenk 1984; De Luca and Cutler 1987). But, McKnight et al. (1991) clearly demonstrated that STR protein is located in the vacuoles of $C$. roseus cells and it was further confirmed that STR activity is located in this compartment (Stevens et al. 1993).

A partial str cDNA clone was isolated from C. roseus by McKnight et al. (1990) but the complete genomic sequence for STR from $C$. roseus was reported by Pasquali et al. (1992). It is encoded by a single gene. Overexpression of the str gene in $C$. roseus resulted in a number of cases in an increase in alkaloid biosynthesis (Canel et al. 1998; Whitmer 1999) but this gradually decreased upon subculturing despite a high level of STR activity.

Cellular investigation showed that $t d c$ and str1 mRNAs were present in the epidermis of stems, leaves, flower buds and appeared in most protoderm and cortical cells of the apical meristem of root tips. The mRNAs of genes-encoding enzymes involved in vindoline biosynthesis are associated with laticifer and idioblast cells of the shoots which is clearly different from TDC and STR localization (St-Pierre et al. 1999).

\section{Biosynthesis of indole alkaloids}

As strictosidine is considered to be a central intermediate in the biosynthetic pathway of monoterpenoid indole alkaloids in $C$. roseus, somewhere beyond this stage in the biosynthesis, routes towards the different specific end products are thought to diverge. Strictosidine- $\beta$-D-glucosidase (SGD) might be the enzyme playing an important role in steering the monoterpenoid indole alkaloid biosynthesis in a specific direction.

\section{Strictosidine- $\beta$-D-glucosidase (E.C. 3.2.1.105)}

The enzyme SGD was first described by Scott et al. (1977). It was thought that this enzyme was present as a large enzyme complex, so-called ajmalicine synthase, capable to form ajmalicine from tryptamine and secologanin. Hemscheidt and Zenk (1980) reported the presence of two 
specific $\beta$-glucosidases from $C$. roseus and both accepted strictosidine as substrate. A partial purification scheme for SGD has been presented by Stevens (1994) using C. roseus and Tabernaemontana divaricata cell cultures as source for the SGD enzyme. Luijendijk et al. (1998) purified the SGD enzyme to apparent homogeneity from $C$. roseus cell suspension cultures. It was reported that SGD has a very high molecular mass but under denaturing conditions a molecular mass of $63 \mathrm{kDa}$ is found suggesting that the native enzyme is occurring as an aggregate where many subunits are bound. Kinetic parameters showed that it has a strong affinity for strictosidine as substrate. It shows a remarkable stability towards proteases as it plays a role in plant's defence.

Subcellular localization studies showed that SGD is most likely associated with the endoplasmic reticulum and this is consistent with the presence of a putative signal sequence for targeting of the protein to the endoplasmic reticulum (Geerlings et al. 2000).

Geerlings et al. (2000) cloned the gene encoding this enzyme from $C$. roseus cell suspension cultures. A full-length clone gave rise to SGD activity when expressed in yeast. SGD is encoded by single copy gene and showed up to $60 \%$ homology at the amino acid level to other $\beta$-glucosidases from plants.

\section{Biosynthesis of ajmalicine, serpentine and tetrahydroalstonine}

The removal of the glucose moiety of strictosidine by SGD leads to an unstable highly reactive aglucon which was thought to be converted into 4,21-dehydrogeissoschizine. The latter was believed to be converted by cathenamine synthase to cathenamine (Rüffer et al. 1979). However, following the conversion of strictosidine by $C$. roseus purified glucosidase by ${ }^{1} \mathrm{H}-\mathrm{NMR}$ did not show any 4,21-dehydrogeissoschizine. The carbinolamine was the intermediate rather than 4,21dehydrogeissoschizine. Apparently the formation of cathenamine from strictosidine does not need cathenamine synthase but only the glucosidase (Stevens 1994).
Cathenamine is reduced to form ajmalicine (Fig. 5). There are two different cathenamine reductases (CRs), one converts cathenamine into ajmalicine and the other converts the iminium form of cathenamine into tetrahydroalstonine (Hemscheidt and Zenk 1980). Ajmalicine is converted into serpentine by basic peroxidase isolated from $C$. roseus vacuoles (Blom et al. 1991). Sierra (1991) found a close correlation between the peroxidase activity and serpentine accumulation. Light grown cell cultures had a 20 fold higher vacuolar peroxidase activity compared to those of dark-grown cells and the accumulation of serpentine in light grown cells was higher.

\section{Enzymes involved in the biosynthesis of ajmalicine, serpentine and tetrahydroalstonine pathways}

\section{$C R$ and tetrahydroalstonine synthase}

The reduction of cathenamine to form ajmalicine is catalysed by the enzyme CR. Early studies by Hemscheidt and Zenk (1985) described this enzyme which used cathenamine as a substrate and NADPH as cofactor resulting in the formation of ajmalicine and 19-epi-ajmalicine. Tetrahydroalstonine synthase (THAS) from C. roseus used the iminium form of cathenamine as substrate and NADPH to form tetrahydroalstonine (Hemscheidt and Zenk 1985). This enzyme showed a $K_{\mathrm{m}}$ of $62 \mu \mathrm{M}$ for this substrate and the enzyme molecular mass was estimated to be $81 \mathrm{kDa}$. Both CR and THAS were detected in low levels in $C$. roseus cell cultures (Luijendijk 1995).

\section{Localization of the enzymes involved in ajmalicine, serpentine and tetrahydroalstonine pathways}

The subcellular localization of the enzymes involved in the biosynthesis of ajmalicine and tetrahydroalstonine in C. roseus cell cultures was studied by Luijendijk (1995). Assays after subcellular fractionation suggested a vacuolar localization of THAS. The CR activity was mostly below the detection limit making it impossible to draw any conclusions. 
Fig. 5 Biosynthesis of ajmalicine, serpentine and tetrahydroalstonine in $C$. roseus. $S G D$ strictosidine glucosidase, $C R$ cathenamine reductase, $P O D$ peroxidase, THAS tetrahydroalstonine synthase

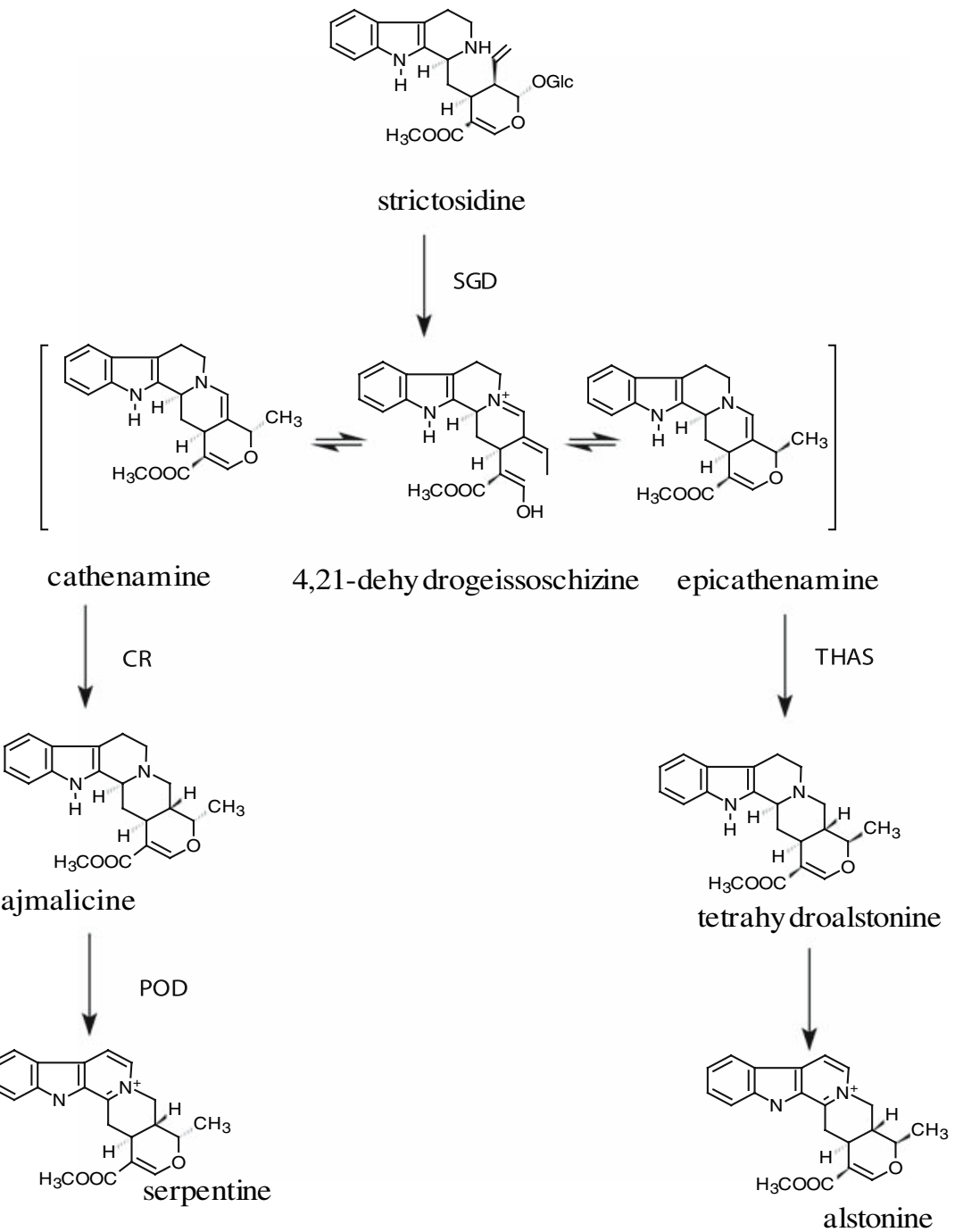

Ajmalicine is channelled across the plasma membrane until it is trapped in a low-pH vacuole by an ion-trap mechanism. The oxidation of ajmalicine to serpentine was shown to be catalysed by a vacuolar peroxidase (Blom et al. 1991).

\section{Catharanthine pathway}

The information on catharanthine biosynthesis is very limited. Battersby and Hall (1969) reported that geissoschizine fed to $C$. roseus plants was incorporated into catharanthine. Brown et al. (1971) suggested that geissoschizine could be converted into stemmadenine or akuammicine. Feeding stemmadenine to $C$. roseus cell suspen- sion cultures resulted in the formation of catharanthine and tabersonine in few hours (El-Sayed et al. 2004). Condylocarpine was also formed after feeding as an oxidation product but not as an intermediate in the pathway.

Enzymes and genes involved in the catharanthine pathway have not been isolated or cloned yet.

\section{Vindoline pathway}

It has been established that tabersonine is transformed into vindoline by a sequence of six steps (Fig. 6). These steps include: aromatic hydroxylation, O-methylation, hydration of the 2,3-double bond, N(1)-methylation, hydroxylation 
at position 4 and 4-O-acetylation (Balsevich et al. 1986; De Luca et al. 1986). The first reaction is catalysed by tabersonine 16-hydroxylase $(\mathrm{T} 16 \mathrm{H})$ yielding 16-hydroxytabersonine. The second step is catalysed by $O$-methyltransferase (OMT) resulting in the formation of 16-methoxytabersonine. De Luca et al. (1987) established that the third step in vindoline biosynthesis is catalysed by an unidentified hydroxylase to form 16-methoxy-2,3-dihydro3 -hydroxytabersonine. The subsequent step is $\mathrm{N}$-methylation of 16-methoxy-2,3-dihydro-3-hydroxytabersonine by $N$-methyltransferase (NMT) forming desacetoxyvindoline. The latter is hydroxylized by desacetoxyvindoline-4-hydroxylase (D4H) into deacetylvindoline. The last step in the biosynthesis of vindoline is acetylation of deacetylvindoline by deacetylvindoline-4- $O$-acetyltransferase (DAT) to form vindoline.

\section{Enzymes involved in the biosynthesis of vindoline}

\section{$T 16 H$ and $O M T$}

Tabersonine 16-hydroxylase and OMT catalyse the first two steps in the vindoline biosynthesis pathway. Characterization of both enzymes was reported by St-Pierre and De Luca (1995). T16H was identified as a membrane-bound cytochrome P450-dependent enzyme with low activity in etiolated seedlings but strongly induced activity by light. OMT used 16-hydroxytabersonine as a natural substrate. These enzymes were recently reported to be localized in leaf epidermal cells, identifying these cells as the major site of vindoline precursor biosynthesis (Murata and De Luca 2005).

\section{N-Methyltransferase}

This enzyme has been partially purified by highperformance anion exchange chromatography on a mono-Q column and has an apparent $M_{\mathrm{r}}$ of 60,000 (Dethier and De Luca 1993). The enzyme has a high substrate specificity where the reduced 2,16 double bond in the tabersonine skeleton is essential.

\section{Desacetoxyvindoline-4-hydroxylase}

The hydroxylation of desacetoxyvindoline is catalysed by a 2-oxoglutarate-dependent dioxygenase $\mathrm{D} 4 \mathrm{H}$. This enzyme was purified to homogeneity

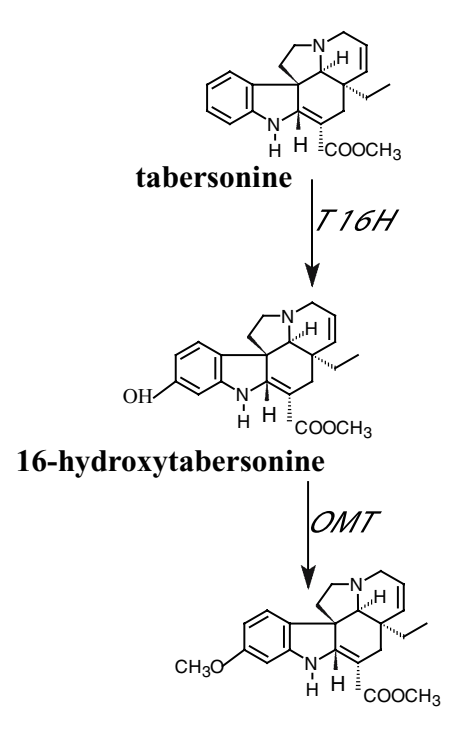

16-methoxytabersonine

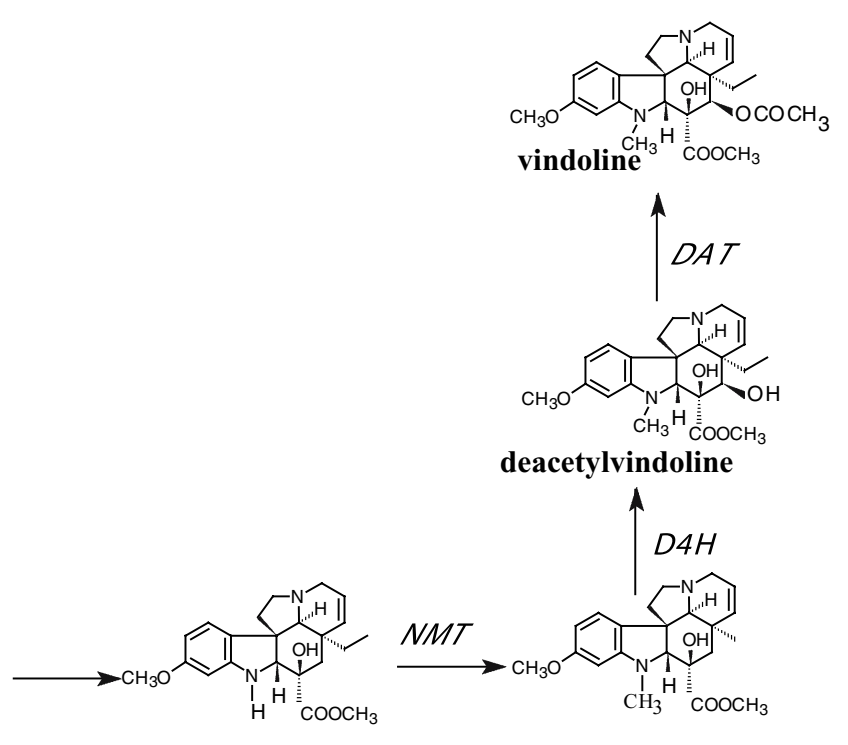

16-methoxy-2,3-dihydro -3-hydroxy-tabersonine

Fig. 6 Vindoline biosynthesis pathway. $T 16 H$ tabersonine 16-hydroxylase, $O M T O$-methyltransferase, $N M T N$-methyltransferase, $D 4 H$ desacetoxyvindoline 4-hydroxylase, $D A T$ deacetylvindoline-4- $O$-acetyltransferase 
and characterized by De Carolis et al. (1990) and De Carolis and De Luca (1993). It requires alkaloid substrate, 2-oxoglutarate, ascorbate, ferrous ions and molecular oxygen for the activity. Exposure of the etiolated seedlings to light or red-light induced the activity of the enzyme (Vasquez-Flota et al. 2000). MJ increased the activity of D4H in etiolated seedlings of $C$. roseus in light conditions but not in the absence of light (Vasquez-Flota and De Luca 1998).

\section{Deacetylvindoline-4-O-acetyltransferase}

Acetyl coenzyme A:DAT catalyses the biosynthesis of vindoline from acetyl coenzyme A and deacetylvindoline. The purified enzyme is strongly inhibited by tabersonine and coenzyme A (50\% inhibition at 45 and $37 \mu \mathrm{M}$, respectively) and weakly inhibited by tryptamine, secologanin and vindoline (Power et al. 1990). The original purification of DAT led to an incorrect conclusion that the enzyme consists of two subunits with molecular weight of 33 and $21 \mathrm{kDa}$. The isolated dat gene encodes a $50 \mathrm{kDa}$ polypeptide suggesting that the protein was cleaved during purification.

\section{Genes-encoding enzymes involved in the vindoline pathway}

A T16H cDNA was cloned from C. roseus cell suspension cultures by Schröder et al. (1999) and expressed in E. coli. The protein (CYP71D12) showed $47-52 \%$ identity with the other members of the CYP71D subfamily with unknown functions.

Vasquez-Flota et al. (1997) reported on the cloning of $\mathrm{D} 4 \mathrm{H}$ gene from $C$. roseus. Three oligopeptides were isolated from the tryptic digest of the purified protein and microsequenced. One oligopeptide showed significant homology to hyoscyamine 6 - $\beta$-hydroxylase. The three clones were confirmed to be authentic $d 4 h$ clones as the heterologous expression of the recombinant protein showed D4H activity. Southern blot analysis suggested that the $d 4 h$ is present as a single copy-gene. Hydroxylation activity and RNA blot hybridization studies showed that the enzyme activity followed closely the levels of $d 4 h$ transcripts, occurring predominantly in young leaves and much lower in stems and fruits. Etiolated seedlings had undetectable activity but rapid increase of enzyme activity of $\mathrm{D} 4 \mathrm{H}$ was shown after exposure to light.

The dat gene was cloned by St-Pierre et al. (1998) from C. roseus leaf extract. The genomic clone encoded a $50 \mathrm{kDa}$ polypeptide. Cleavage of DAT protein to yield a heterodimer appears to be an artefact of the protein purification procedure. The study showed that the induced dat mRNA, protein accumulation and the enzyme activity occurred in leaves and cotyledons of light-treated seedlings. The southern blot of genomic DNA isolated from $C$. roseus indicated that the dat occurs as a single copy-gene.

\section{Localization of the enzymes involved in the vindoline biosynthesis pathway}

Tabersonine 16-hydroxylase is a cytochrome P450-dependent monooxygenase associated with the external face of the endoplasmic reticulum while OMT is believed to occur in the cytosol (StPierre and De Luca 1995). NMT is associated with the chloroplast thylakoids (De Luca 1993). D4H and DAT are cytosolic enzymes (St-Pierre et al. 1998; Vasquez-Flota et al. 1997). St-Pierre et al. (1999) reported that D4H and DAT mRNAs were associated with the laticifer and idioblast cells of the leaves, stems and flower buds. These results suggest that the late steps of vindoline biosynthesis occur in a specific tissue, explaining that the attempts to produce vindoline by cell culture technology have failed so far.

\section{Biosynthesis of bisindole alkaloids}

The bisindole alkaloids vinblastine and vincristine are of great interest. They are synthesized from the coupling of the monomeric alkaloids catharanthine and vindoline. The product resulting from the coupling is $\alpha-3^{\prime}, 4^{\prime}$-anhydrovinblastine which is converted into vinblastine which is further converted into vincristine (for review, see Verpoorte et al. 1997). The coupling process is catalysed by the enzyme anhydrovinblastine 
synthase (AVLBS). These dimeric alkaloids are used as antitumour agents and produced in trace amounts $(0.003 \%$ dry weight). The natural high abundance of vindoline and catharanthine in $C$. roseus plants led to the establishment of a semisynthetic process for coupling the monomers either chemically (Langlois et al. 1976; Kutney et al. 1976) or enzymatically using horseradish peroxidase (Goodbody et al. 1988).

\section{The basic peroxidase enzyme catalysing the dimerization process}

The search of the enzyme responsible for the dimerization reaction using crude enzyme extracts failed to detect any significant dimerization activity. This was referred to the presence of enzyme inhibitors released from the different cellular compartments during homogenization (Sottomayor et al. 1996). After purification of the protein extracts, dimerization was detected in the fractions containing peroxidase activity and dependent on the presence of $\mathrm{H}_{2} \mathrm{O}_{2}$, this enzyme was identified as AVLBS (Sottomayor et al. 1998). Coupling vindoline with catharanthine by a peroxidase into anhydrovinblastine which is a reduction product from a highly instable dihydropyridinium, an iminium, is the true precursor to the other bisindole alkaloids vinblastine, vincristine and leurosine (Fig. 1). The purified protein showed a specific activity of $1.8 \mathrm{nkat} / \mathrm{mg}$. Molecular weight was estimated to be $45.4 \mathrm{kDa}$ and the $\mathrm{p} I$ of the protein around 10.7 . The enzyme was a high spin ferric haem protein belonging to the class III peroxidase family.

The localization of the enzyme has been reported to occur in the vacuole associated to specific spots of the internal face of the tonoplast (Sottomayor et al. 1996).

\section{Gene encoding basic peroxidase}

Beginning with purified CRPRX1 (basic peroxidase) protein, the polypeptide N-terminal region was sequenced. By this process $11 \mathrm{~N}$-terminal amino acids were identified. Further molecular strategies failed to give more cloning information results. A PCR strategy followed by screening of a cDNA library prepared from $C$. roseus leaf tissue enabled the preparation of a full-length cDNA clone which considered to be CrPrx1 cDNA (Hilliou et al. 2002).

\section{Regulation of TIA biosynthesis}

Regulation of TIAs can be controlled either by developmental or exogenous signals. Light is thought to have an effect on enzyme induction and activation. Stimulation of serpentine accumulation in cells and tissue cultures and oxidation of ajmalicine depends on light (Loyola-Vargas et al. 1992). Part of the vindoline biosynthetic pathway is also regulated by light (St-Pierre and De Luca 1995). In C. roseus callus cultures, Zhao et al. (2001a) found that light significantly influenced the biosynthesis of vindoline. In the same study, the group confirmed that stimulation of plastidial basic and acidic peroxidases by light led to induction of serpentine accumulation. Shanks and Bhadra (1997) established a light-adapted C. roseus hairy root culture that exhibited green pigmentation but with lower tabersonine, hörhammericine and lochnericine levels and an increase in specific yields of ajmalicine and serpentine compared to dark-grown cultures.

Application of various exogenous chemicals can improve the alkaloid production of C. roseus. Betaine, malic acid, tetramethyl ammonium bromide and rare elements increased the yields of ajmalicine and catharanthine in cell cultures about five- to sixfold (Zhao et al. 2000a, b). Zheng and $\mathrm{Wu}$ (2004) found that treating C. roseus cell suspension cultures with cadmium resulted in enhancement of ajmalicine content as well as TDC enzyme activity. The use of oxygenase inhibitors in hairy root cultures inhibited the accumulation of lochnericine and hörhammericine suggesting that these chemicals influenced the cytochrome $\mathrm{P} 450$ enzymes that may be responsible for the formation of these alkaloids (Morgan and Shanks 1999). G10H, a cytochrome P450 enzyme activity increased by addition of phenobarbital and decreased by ketoconazole (Contin et al. 1999).

Increasing the substrate supply via precursor feeding overcomes the rate-limiting steps in 
the production of alkaloids. Particularly the terpenoid pathway seems rate limiting for alkaloid production and feeding with secologanin or loganin has proven to be an efficient way to improve accumulation of alkaloids (Moreno et al. 1993; Whitmer et al. 1998 and Contin 1999). Feeding both tryptamine and loganin to transgenic cell cultures resulted in very high production levels (Whitmer et al. 1998). Feeding either geraniol, 10hydroxygeraniol or loganin to a $C$. roseus hairy root culture resulted in significant increases in the accumulation of tabersonine (Morgan and Shanks 2000). But addition of tryptophan or tryptamine separately had no effect. It seems that a part of the pathway is present in the plant cell cultures. These enzymes do have a considerable capacity for alkaloid production. The flux is thus determined in an early phase of the pathway. Particularly the terpenoid part of the pathway seems limiting for the alkaloid production.

\section{Plant growth regulators}

The role of growth hormones in regulation of C. roseus indole alkaloids has been extensively studied (for review see Moreno et al. 1995 and Verpoorte et al. 1997). They affect both culture growth and secondary metabolite production. Auxins negatively influence alkaloid biosynthesis at all levels. Subculturing cells on an auxin-free medium, results in increased $T d c$ and Str mRNA levels, while addition of auxins rapidly decreases the $T d c$ mRNA level. 2,4-D strongly inhibits alkaloid production essentially during the growth phase (Arvy et al. 1994). Cytokinins are very important growth regulators which regulate many aspects of plant growth and differentiation. Addition of zeatin to an auxin-free $C$. roseus cell cultures resulted in an increase in alkaloid accumulation (Decendit et al. 1992). Zeatin enhanced the activity of $\mathrm{G} 10 \mathrm{H}$ and the bioconversion of secologanin to ajmalicine in C. roseus cultures (Decendit et al. 1993). Exogenously applied cytokinins to untransformed $C$. roseus callus or cell suspension cultures increased the content of ajmalicine and serpentine (Garnier et al. 1996; Yahia et al. 1998).

Abscisic acid (ABA) regulates various aspects of plant growth and development including seed maturation and dormancy, as well as adaptation to abiotic environmental stresses (Davies and Jones 1991; Beaudoin et al. 2000). Smith et al. (1987) reported that ABA stimulated accumulation of catharanthine and vindoline in $C$. roseus. Treatment of precursors fed $C$. roseus cells with ABA did not induce the accumulation of alkaloids but it delayed the catabolism of strictosidine (El-Sayed and Verpoorte 2002).

\section{Jasmonate}

Jasmonic acid or MJ are used as exogenous signal transduction compounds (reviewed by Reymond and Farmer 1998). Addition of jasmonic acid to C. roseus hairy root cultures increased the yield of alkaloids (Rijhwani and Shanks 1998).

Treatment of C. roseus seedlings with $\mathrm{MJ}$ resulted in doubling of alkaloid accumulation (Aerts et al. 1994). Upon feeding precursors to C. roseus cell cultures and treating with $\mathrm{MJ}$, strictosidine and ajmalicine accumulation was increased (El-Sayed and Verpoorte 2002). Octadecanoid-responsive Catharanthus AP2/ERF-domain (ORCA) transcription factors have been shown to regulate the $\mathrm{JA}$-responsive activation of several TIA biosynthetic genes (Van der Fits and Memelink 2000; Memelink et al. 2001). ORCA2, a transcription factor of AP2/ERF domain transactivated str promoter activity by sequence-specific binding to the JERE (Menke et al. 1999). ORCA3, a novel jasmonate-responsive AP2domain transcriptive factor was isolated from $C$. roseus by T-DNA tagging (Van der Fits and Memelink 2000). It is similar to ORCA2 in the AP2/ERF DNA-binding domain. Also expression of the gene was induced by MJ with similar kinetics as ORCA2. The ORCA3 protein binds to the promoter regions of the TIA biosynthetic genes $s t r, t d c$ and $c p r$, the CPR (Van der Fits and Memelink 2001). Overexpression of ORCA3, resulted in induction of expression of many secondary and primary metabolite biosynthetic genes, though TIAs production increased only upon feeding loganin to the ORCA3 overexpressing cells (Van der Fits and Memelink 2000). Again this shows the important role of the iridoid pathway for determining the final alkaloid levels. 


\section{Salicylic acid}

Salicylic acid has been shown to be an important compound in the defence system of plants. However, addition of SA to C. roseus, either seedlings (Aerts et al. 1996) or cell cultures (El-Sayed and Verpoorte 2002) did not affect the yield of alkaloids. A weak inducing effect on Str and $T d c$ steady-state mRNA levels was observed in C. roseus after addition of $0.1 \mathrm{mM}$ SA (Pasquali 1994).

\section{Fungal elicitation}

The biosynthesis of TIAs can be stimulated by addition of exogenous elicitors such as fungal preparations. Many studies reveal that fungal elicitors profoundly affect regulation of indole alkaloid biosynthesis (for review see Verpoorte et al. 1997). In the past 20 years, plant microbe interactions and plant defence responses have been studied extensively. Pathogen recognition at the cell surface or in the cytosol initiates various cellular signalling processes that activate multicomponent plant defence responses, such as oxidative burst defence gene activation and accumulation of defence-related compounds (Mehdy 1994; Chandra et al. 1997; Scheel 1998). Menke et al. (1999) reported induction of the $t d c$ and str genes in C. roseus cells by fungal elicitors suggesting that the octadecanoid pathway may be involved in fungal elicitor-induced indole alkaloid production. In C. roseus, Moreno et al. (1996) measured activities of some enzymes involved in secondary metabolism before and after fungal elicitation and found that TDC activity is highly induced while $\mathrm{G} 10 \mathrm{H}$ and IPP-isomerase activities are slightly decreased by elicitation. Although the strong and rapidly stimulating effect of fungal elicitors on plant secondary metabolite accumulation attracts considerable attention, contradictory results are sometimes observed. Great efforts are being made to investigate the mechanism of fungal elicitors at physiological and molecular levels. The mechanism of elicitation in plants is based on elicitor-receptor interaction after which a rapid array of biochemical responses occur (Radman et al. 2003). Figure 7 shows the possible elicitor mechanism of action. The mechanism includes: (1) binding of the elicitor to plasma membrane receptor. (2) Changes in $\mathrm{Ca}^{2+}$ influx to the cytoplasm from extracellular and intracellular pools. (3) Changes in the protein phosphorylation patterns and protein kinase activation. (4) Decrease of $\mathrm{pH}$ of the cytoplasm and activation of NADPH oxidases. (5) Changes in cell wall structure (lignification) through generating reactive oxygen species. (6) Synthesis of jasmonic acid and salicylic acid as secondary messengers. (7) Accumulation of defence-related proteins. (8) Synthesis of plant defence molecules such as phytoalexins. (9) Systemic acquired resistance.

Zhao et al. (2001c) screened 12 fungal elicitors to improve indole alkaloid production in $C$. roseus cell suspension cultures. Different kinds of alkaloids are induced by different fungal elicitors and different elicitor dosages. Combination of abiotic and biotic elicitors added to $C$. roseus cell suspension cultures resulted in improvement of TIA production. Ajmalicine and catharanthine are induced by addition of tetramethyl ammonium bromide and Aspergillus niger homogenate (Zhao et al. 2001b).

\section{Metabolic engineering}

Recently a number of examples of plant transformation were addressed (for review, see Verpoorte et al. 2000, 2002; Verpoorte and Alfermann 2000). Single or multiple steps of the pathway can be introduced in the plant genome to improve productivity of secondary metabolites. C. roseus is a model from which genes encoding key enzymes (TDC, STR and G10H) involved in TIAs were overexpressed in different plants. Strictosidine production, the central intermediate in the TIA pathway can be achieved in tobacco expressing Catharanthus tdc and str genes upon feeding secologanin (Hallard et al. 1997). Expression of those genes in Morinda citrifolia cells also resulted in strictosidine formation when the cells were fed with tryptamine and secologanin (Hallard 2000). Hairy roots of Weigela 'styriaca' expressing str and $t d c$ cDNAs from $C$. roseus are able to produce tryptamine and ajmalicine (Hallard 2000). In C. roseus, overexpression of 


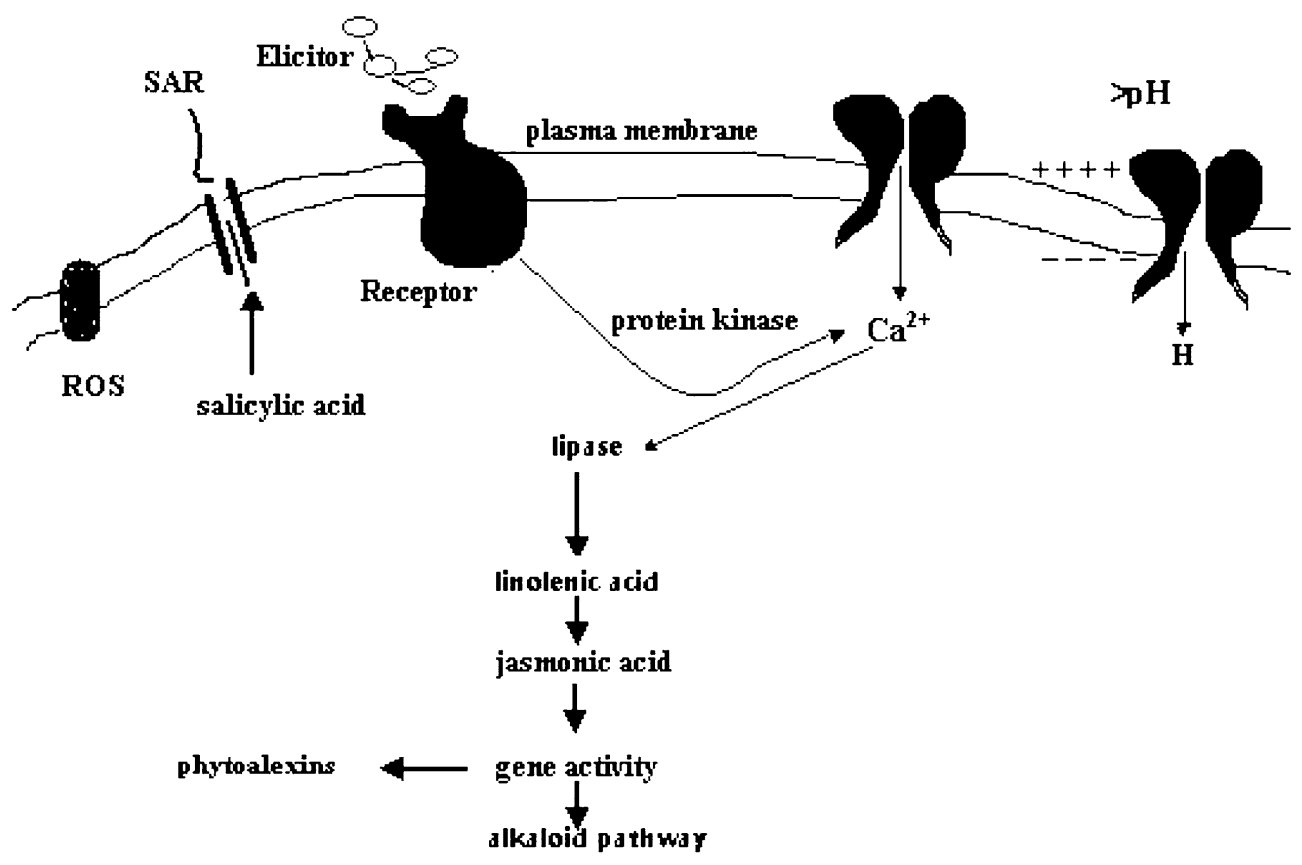

Fig. 7 Elicitor action mechanism in plant cell

the gene encoding the enzyme STR resulted in some cases in an increase in alkaloid biosynthesis. Although those transgenic cell lines of $C$. roseus overexpressing $t d c$ and str lost their capacity to produce high levels of alkaloids after 2 years subculturing, the enzymes of both transgenes remained high (Whitmer 1999). Feeding such cell cultures with loganin increased alkaloid production considerably, by adding also tryptamine, high levels (ca $400 \mathrm{mg} / \mathrm{l}$ ) of alkaloids could be obtained (Whitmer et al. 2002a,b). Overexpressing AS in hairy roots resulted in an increased level of tryptophane and tryptamine, but no increase of the major alkaloids. Again confirming the limiting role of the iridoid pathway (Hughes et al. 2004a). In combination with TDC a similar result was obtained, whereas overexpression of TDC alone gave an increase in serpentine (Hughes et al. 2004b).

\section{Conclusions}

There are over 100 indole alkaloids produced by C. roseus but the biosynthetic pathway to these alkaloids is not fully characterized yet. Recently, much progress was achieved in the terpenoid pathway especially the discovery of the MEP pathway leading to the isoprenoid formation. It was confirmed that in $C$. roseus, secologanin is derived from this pathway and the enzyme converting loganin to secologanin was characterized. Although the MEP pathway was given much attention in microbes, in $C$. roseus so far only three early steps in the pathway including enzymes and gene cloning were reported. In the last few years, the majority of work done in C. roseus focussed on the regulation of alkaloid production via many different applications such as feeding precursors, elicitation or metabolic engineering. Jasmonate is a well-established general inducer of a large number of genes in the pathway resulting in an improved alkaloid production. Overexpression of biosynthetic genes in C. roseus has so far failed to significantly increase sustainable production of the desired alkaloids. Joining expression of regulatory genes together with those controlling limiting steps that are not upregulated by the regulatory genes in the pathway may be of interest to overcome these problems. Still several parts of the pathway need to be elucidated at the level of intermediates. 
Proteomics and metabolomics approaches may be useful to identify the genes and enzymes involved. However, one need to consider also the involvement of transport in the regulation of the biosynthesis as different parts of the pathway are present in different cellular compartments and even different cells.

\section{References}

Aerts RJ, Gisi D, De Carolis E, De Luca V, Baumann TW (1994) Methyl jasmonate vapor increases the developmentally controlled synthesis of alkaloids in Catharanthus roseus and Cinchona seedlings. Plant J 5:635-643

Aerts RJ, Schafer A, Hesse M, Baumann TW, Slusarenko A (1996) Signalling molecules and the synthesis of alkaloids in Catharanthus roseus seedlings. Phytochemistry 42:417-422

Albrecht M, Sandmann G (1994) Light-stimulated carotenoid biosynthesis during transformation of maize etioplast is regulated by increased activity of isopentenyl pyrophosphate isomerase. Plant Physiol 105:529-534

Arigoni D, Sagner S, Latzel C, Eisenreich W, Bacher A, Zenk MH (1997) Terpenoid biosynthesis from 1-deoxy-D-xylulose in higher plants by intramolecular skeletal rearrangement. Proc Natl Acad Sci USA 94:10600-10605

Arvy MP, Imbault N, Naudascher F, Thiersault M, Doireau P (1994) 2,4-D and alkaloid accumulation in periwinkle cell suspensions. Biochimie 76:410-416

Ayora-Talavera T, Chappell J, Lozoya-Gloria E, LoyolaVargas VM (2002) Overexpression in Catharanthus roseus hairy roots of a truncated hamster 3-hydroxy-3methylglutaryl-CoA reductase gene. Appl Biochem Biotechnol 97:135-145

Bach TJ (1995) Some new aspects of isoprenoid biosynthesis in plants-a review. Lipids 30:191-202

Bach TJ, Raudot V, Vollack KU, Weber T, Zeiler S (1994) Further studies on the enzymatic conversion of acetyl-coenzyme A into 3-hydroxy-3-methylglutarylcoenzyme $\mathrm{A}$ in radish. Plant Physiol Biochem 32:775-783

Balsevich J, De Luca V, Kurz WGW (1986) Altered alkaloid pattern in dark grown seedlings of Catharanthus roseus. The isolation and characterization of 4desacetoxyvindoline: a novel indole alkaloid and proposed precursor of vindoline. Heterocycles 24:2415-2421

Battersby AR, Hall ES (1969) The intermediacy of geissoschizine in indole alkaloid biosynthesis: rearrangement to the Strychnos skeleton. Chem Commun 14:793-794

Beaudoin N, Serizet C, Gosti F, Giraudat J (2000) Interactions between abscisic acid and ethylene signaling cascade. Plant Cell 12:1103-1115
Bongaerts RJM (1998) The chorismate branching point in Catharanthus roseus: aspects of anthranilate synthase regulation in relation to indole alkaloid biosynthesis. PhD thesis, Leiden University, The Netherlands

Brown RT, Hill JS, Smith GF, Stapleford HSJ (1971) On the rearrangement of catharanthine, stemmadenine and tabersonine in acetic acid. Tetrahedron 27:5217-5228

Burlat V, Oudin A, Courtois M, Rideau M, St-Pierre B (2004) Co-expression of the three MEP pathway genes and geraniol 10-hydroxylase in internal phloem parenchyma of Catharanthus roseus implicates multicellular translocation of intermediates during the biosynthesis of monoterpene indole alkaloids and isoprenoidderived primary metabolites. Plant J 38:131-141

Canel C, Lopez-Cradoso MI, Whitmer S, van der Fits L, Pasquali G, van der Heijden R, Hoge JHC, Verpoorte R (1998) Effects of overexpression of strictosidine synthase and tryptophan decarboxylase on alkaloid production by cell cultures of Catharanthus roseus. Planta 205:414-419

Chahed K, Oudin A, Guivarc'h N, Hamdi S, Chenieux JC, Rideau M, Clastre M (2000) 1-Deoxy-D-xylulose-5phosphate synthase from periwinkle: cDNA identification and induced gene expression in terpenoid indole alkaloid-producing cells. Plant Physiol Biochem 38:559-566

Chandra S, Stennis M, Low PS (1997) Measurement of $\mathrm{Ca}^{2+}$ fluxes during elicitation of the oxidative burst in aequonin-transformed tobacco cells. J Biol Chem 272:28274-28280

Chappell J (1995) The biochemistry and molecular biology of isoprenoid metabolism. Plant Physiol 107:1-6

Collu G (1999) Geraniol 10-hydroxylase, a cytochrome P450 enzyme involved in the biosynthesis of terpenoid indole alkaloids in higher plants: an enzymological and molecular study. PhD thesis, Leiden University

Collu G, Unver N, Peltenburg-Looman AMG, van der Heijden R, Verpoorte R, Memelink J (2001) Geraniol 10-hydroxylase, a cytochrome P450 enzyme involved in terpenoid indole alkaloid biosynthesis. FEBS Lett 508:215-220

Collu G, Garcia AA, van der Heijden R, Verpoorte R (2002) Activity of the cytochrome P450 enzyme geraniol 10-hydroxylase and alkaloid production in plant cell cultures. Plant Sci 162:165-172

Contin A (1999) The biosynthesis of secologanin in Catharanthus roseus cell suspension cultures. $\mathrm{PhD}$ thesis, Leiden University, The Netherlands

Contin A, van der Heijden R, Lefeber A, Verpoorte R (1998) The iridoid glucoside secologanin is derived from the novel triose phosphate/pyruvate pathway in a Catharanthus roseus cell culture. FEBS Lett 434:413-416

Contin A, Collu G, van der Heijden R, Verpoorte R (1999) The effects of phenobarbital and ketoconazole on the alkaloid biosynthesis in Catharanthus roseus cell suspension cultures. Plant Physiol Biochem 37:139-144

Davies WJ, Jones HG (1991) Abscisic acid physiology and biochemistry. Bioscientific Publishers, Oxford, UK 
De Carolis E, De Luca V (1993) Purification, characterization and kinetic analysis of a 2-oxoglutaratedependent dioxygenase involved in vindoline biosynthesis from Catharanthus roseus. J Biol Chem 268:5504-5511

De Carolis E, Chan F, Balsevich J, De Luca V (1990) Isolation and characterization of a 2-oxoglutarate dependent dioxygenase involved in the second-to-last step in vindoline biosynthesis. Plant Physiol 94:13231329

Decendit A, Liu D, Ouelhazi L, Doireau P, Mèrillon JM, Rideau M (1992) Cytokinin-enhanced accumulation of indole alkaloids in Catharanthus roseus cell cultures - the factors affecting the cytokinin response. Plant Cell Rep 11:400-403

Decendit A, Petit G, Andreu F, Doireau P, Mèrillon JM, Rideau M (1993) Putative sites of cytokinin action during their enhancing effect on indole alkaloid accumulation in periwinkle cell suspensions. Plant Cell Rep 12:710-712

De Luca V (1993) Enzymology of indole alkaloid biosynthesis. In: Lea PJ (ed) Methods in plant biochemistry, enzymes of secondary metabolism. Academic, London, pp 345-368

De Luca V, Cutler AJ (1987) Subcellular localization of enzymes involved in indole alkaloid biosynthesis in Catharanthus roseus. Plant Physiol 85:1099-1102

De Luca V, Balsevich J, Tyler RT, Eilert U, Panchuk BD, Kurz WGW (1986) Biosynthesis of indole alkaloids: development regulation of the biosynthetic pathway from tabersonine to vindoline in Catharanthus roseus. J Plant Physiol 125:147-156

De Luca V, Balsevich J, Tyler RT, Kurz WGW (1987) Characterization of a novel $N$-methyltransferase (NMT) from Catharanthus roseus. Plant Cell Rep 6:458-461

De Luca V, Marineau C, Brisson N (1989) Molecular cloning and analysis of cDNA encoding a plant tryptophan decarboxylase: comparison with animal DOPA decarboxylase. Proc Natl Acad Sci USA 86:2582-2586

Dethier M, De Luca V (1993) Partial purification of a $N$ methyltransferase involved in vindoline in Catharanthus roseus. Phytochemistry 32:673-678

Deus-Neumann B, Zenk MH (1984) Instability of indole alkaloid production in Catharanthus roseus cell suspension cultures. Planta Med 50:427-431

De Waal A, Meijer AH, Verpoorte R (1995) Strictosidine synthase from Catharanthus roseus: purification and characterization of multiple forms. Biochem $\mathrm{J}$ 306(2):571-580

Diez E, Montamat F, Delrot S, Boronat A (1997) Expression of Arabidopsis thaliana 3-hydroxy-3-methylglutaryl-coenzyme A synthase in Escherichia coli. In: Abstract book, 3rd Terpnet meeting, Université de Poitier, France, 29-30 May

Dubey VS, Bhalla R, Luthra R (2003) An overview of non-mevalonate pathway for terpenoid biosynthesis in plants. J Biosci 28:101-110

Duvold T, Bravo JM, Pale-Grosdemange C, Rohmer M (1997a) Biosynthesis of 2-C-methyl-D-erythritol, a putative C-5 intermediate in the mevalonate independent pathway for isoprenoid biosynthesis. Tetrahedron Lett 38:4769-4772

Duvold T, Cali P, Bravo JM, Rohmer M (1997b) Incorporation of 2-C-methyl-D-erythritol, a putative isoprenoid precursor in the mevalonate-independent pathway, into ubiquinone and menaquinone of Escherichia coli. Tetrahedron Lett 38:6181-6184

Eilert U, Kurz WG, Constabel F (1987) In: Green CE (ed) Plant cell and tissue culture. A. R. Liss, New York, p 213

Eisenreich W, Menhard B, Hylands PJ, Zenk MH, Bacher A (1996) Studies on the biosynthesis of taxol: the taxane carbon skeleton is not mevalonoid origin. Proc Natl Acad Sci USA 93:6431-6436

Eisenreich W, Sagner S, Zenk MH, Bacher A (1997) Monoterpenoid essential oils are not of mevalonoid origin. Tetrahedron Lett 38:3889-3892

El-Sayed M, Verpoorte R (2002) Effect of phytohormones on growth and alkaloid accumulation by a Catharanthus roseus cell suspension cultures fed with alkaloid precursors tryptamine and loganin. Plant Cell Tissue Organ Cult 68:265-270

El-Sayed M, Choi YH, Frédérich M, Roytrakul S, Verpoorte R (2004) Alkaloid accumulation in Catharanthus roseus cell suspension cultures fed with stemmadenine. Biotechnol Lett 26:793-798

Enjuto M, Balcells L, Campos N, Caelles C, Arró M, Boronat A (1994) Arabidopsis thaliana contains two differentially expressed 3-hydroxy-3-methylglutarylcoenzyme A reductase genes, which encode microsomal forms of the enzyme. Proc Natl Acad Sci USA 91:927-931

Facchini PJ, DiCosmo F (1991) Secondary metabolites biosynthesis in cultured cells of Catharanthus roseus (L.) Don immobilized by adhesion to glass fibers. Appl Microbiol Biotechnol 35:382-392

Fernandez JA, Owen TG, Kurz WG, De Luca V (1989) Immunological detection and quantitation of tryptophan decarboxylase in developing Catharanthus roseus seedlings. Plant Physiol 91:79-84

Garnier F, Carpin S, Label P, Crèche J, Rideau M, Hamdi S (1996) Effect of cytokinin on alkaloid accumulation in periwinkle callus cultures transformed with a lightinducible ipt gene. Plant Sci 120:47-55

Gary JC (1987) Control of isoprenoid biosynthesis in higher plants. Adv Bot Res 14:25-90

Geerlings A, Memelink J, van der Heijden R, Verpoorte R (2000) Molecular cloning and analysis of strictosidine $\beta$-D-glucosidase, an enzyme in terpenoid indole alkaloid biosynthesis in Catharanthus roseus. J Biol Chem 275:3051-3056

Goddijn OJM (1992) Regulation of terpenoid indole alkaloid biosynthesis in Catharanthus roseus. $\mathrm{PhD}$ thesis, Leiden University, The Netherlands

Goddijn OJM, De Kam RJ, Zanetti A, Schilperoort RA, Hoge JHC (1992) Auxin rapidly down-regulates transcription of the tryptophan decarboxylase gene from Catharanthus roseus. Plant Mol Biol 18:113-120

Goddijn OJM, Pennings EJM, van der Helm P, Verpoorte R, Hoge JHC (1995) Overexpression of a tryptophan decarboxylase cDNA in Catharanthus roseus crown 
gall calluses results in increased tryptamine levels but not in increased terpenoid indole alkaloid production. Transgenic Res 4:315-323

Goodbody AE, Endo T, Vukovic J, Kutney JP, Choi LSL, Misawa M (1988) Enzymatic coupling of catharanthine and vindoline to form $3^{\prime}, 4^{\prime}$-anhydrovinblastine by horseradish peroxidase. Planta Med 54:136-140

Green TR, Dennis DT, West CA (1975) Compartmentation of isopentenyl pyrophosphate isomerase and pyrenyltransferase in developing castor bean endosperm. Biochem Biophys Res Commun 64:976-982

Grolle S, Bringer-Meyer S, Sahm H (2000) Isolation of the $d x r$ gene of Zymomonas mobilis and characterization of the 1-deoxy-D-xylulose-5-phosphate reductoisomerase. FEMS Microbiol Lett 191:131-137

Guarnaccia R, Botta L, Coscia CJ (1974) Biosynthesis of acidic iridoid monoterpene glucosides in Vinca rosea. J Am Chem Soc 96:7079-7084

Hallard D (2000) Transgenic plant cells for the production of indole alkaloids. PhD thesis, University of Leiden, The Netherlands

Hallard D, van der Heijden R, Verpoorte R, Lopes Cardoso M, Pasquali G, Memelink J, Hoge JHC (1997) Suspension cultured transgenic cells of Nicotiana tabacum expressing tryptophan decarboxylase and strictosidine synthase cDNA from Catharanthus roseus produce strictosidine upon secologanin feeding. Plant Cell Rep 17:50-54

Hampton RY, Rine J (1994) Regulated degradation of HMG-CoA reductase, an integral membrane protein of the endoplasmic reticulum in yeast. J Cell Biol 125:299-312

Hemscheidt T, Zenk MH (1980) Glucosidases involved in indole alkaloid biosynthesis of Catharanthus roseus cell cultures. FEBS Lett 110:187-191

Hemscheidt T, Zenk MH (1985) Partial purification and characterization of a NADPH dependent tetrahydroalstonine synthase from Catharanthus roseus cell suspension cultures. Plant Cell Rep 4:216-219

Hilliou F, Costa M, Almeida I, Lopes Cardoso I, Leech M, Ros Barcelo A, Sottomayor M (2002) Cloning of a peroxidase enzyme involved in the biosynthesis of pharmaceutically active terpenoid indole alkaloids in Catharanthus roseus (L.) G. Don. In: Acosta M, Rodriguez-Lopez JN, Pedreno MA (eds) Proceedings of the VI international plant peroxidase symposium, University of Murcia and University of A Coruna, pp 152-158

Hughes EH, Hong SB, Gibson SI, Shanks JV, San KY (2004a) Expression of a feedback-resistant anthranilate synthase in Catharanthus roseus hairy roots provides evidence for tight regulation of terpenoid indole alkaloid levels. Biotechnol Bioeng 86:718-727

Hughes EH, Hong SB, Gibson SI, Shanks JV, San KY (2004b) Metabolic engineering of the indole pathway in Catharanthus roseus hairy roots and increased accumulation of tryptamine and serpentine. Metab Eng 6:268-276

Irmler S, Schröder G, St-Pierre B, Crouch NP, Hotze M, Schmidt J, Strak D, Matern U, Schröder J (2000) Indole alkaloid biosynthesis in Catharanthus roseus: new enzyme activities and identification of cytochrome P450 CYP72A1 as secologanin synthase. Plant J 24:797-804

Jacobs D (2003) Proteome analysis of the medicinal plant Catharanthus roseus. $\mathrm{PhD}$ thesis, University of Leiden, The Netherlands

Jacobs DI, Gaspari M, van der Greef J, van der Heijden R, Verpoorte R (2005) Proteome analysis of Catharanthus roseus cultured cells for the identification of proteins involved in alkaloid biosynthesis and finding of novel sequences. Planta 221:690-704

Jossang A, Fodor P, Bodo B (1998) A new structural class of bisindole alkaloids from the seeds of Catharanthus roseus: vingramine and methylvingramine. J Org Chem 63:7162-7167

Katayama S, Adachi N, Takao K, Nagakawa T, Matsuda H, Kawamukai M (1995) Molecular cloning and sequencing of the hcs gene which encodes 3-hydroxy-3-methylglutaryl-coenzyme A synthase of Schizosaccharomyces pombe. Yeast 11:1533-1537

Knobloch KH, Berlin J (1983) Influence of phosphate on formation of indole alkaloids and phenolic compounds in cell suspension cultures of Catharanthus roseus. I. Comparison of enzyme activities and product accumulation. Plant Cell Tissue Organ Cult 2:233-240

Knobloch KH, Hansen B, Berlin J (1981) Medium induced formation of indole alkaloids and concomitant changes of interrelated enzyme activities in cell suspension cultures of Catharanthus roseus. Z Naturforsch 36c:40-43

Korth KL, Stermer BA, Bhattacharyya MK, Dixon RA (1997) HMG-CoA reductase gene families that differentially accumulate transcripts in potato tubers are developmentally expressed in floral tissues. Plant Mol Biol 33:545-551

Kutchan TM (1993) Strictosidine: from alkaloid to enzyme to gene. Phytochemistry 32:493-506

Kutney PJ, Hibino T, Jahngen E, Okutani T, Ratcliffe AH, Treasurywala AM, Wunderly SL (1976) Total synthesis of indole and dihydroindole alkaloids. IX. Studies on the synthesis of bisindole alkaloids in the vinblastine-vincristine series. The biogenetic approach. Helv Chim Acta 59:2858-2882

Lange BM, Croteau R (1999) Isopentenyl diphosphate biosynthesis via a mevalonate-independent pathway: isopentenyl monophosphate kinase catalyzes the terminal enzymatic step. Proc Natl Acad Sci USA 96:13714-13719

Lange BM, Wildung MR, McCaskill D, Croteau R (1998) A family of transketolases that directs isoprenoid biosynthesis via a mevalonate-independent pathway. Proc Natl Acad Sci USA 95:2100-2014

Langlois N, Gueritte F, Langlois Y, Potier P (1976) Application of a modification of the Polonovski reaction to the synthesis of vinblastine-type alkaloids. J Am Chem Soc 98:7017-7024

Leivar P, González VM, Castel S, Trelease RN, LópezIglesias C, Arró M, Boronat A, Campos N, Ferrer A, Fernàndez-Busquets $\mathrm{X}$ (2005) Subcellular localization of Arabidopsis 3-hydroxy-3-methylglutaryl-coenzyme A reductase. Plant Physiol 137:57-69 
Lichtenthaler HK (1999) The 1-deoxy-D-xylulose-5-phosphate pathway of isoprenoid biosynthesis in plants. Annu Rev Plant Physiol Plant Mol Biol 50:47-65

Lois LM, Campos N, Putra SR, Danielsen K, Rohmer M, Boronat A (1998) Cloning and characterization of a gene from Escherichia coli encoding a transketolaselike enzyme that catalyzes the synthesis of 1-deoxyxylulose-5-phosphate, a common precursor of isoprenoid, thiamin, and pyridoxol biosynthesis. Proc Natl Acad Sci USA 95:2105-2110

Lopes Cardoso MI (1995) Analysis and modification of the expression of genes involved in plant secondary metabolism: genes encoding early steps in terpenoid indole biosynthesis in Catharanthus roseus. PhD thesis, Catholic University, Portugal

Lopes Cardoso MI, Meijer AH, Rueb S, Queiroz Machado J, Memelink J, Hoge JHC (1997) A promoter region that controls basal and elicitor-inducible expression levels of the NADPH: cytochrome P450 reductase gene $(\mathrm{Cpr})$ from Catharanthus roseus binds nuclear factor GT-1. Mol Gen Genet 256:674-681

Loyola-Vargas V, Mendez-Zeel M, Monforte-Gonzalez M, Miranda-Ham ML (1992) Serpentine accumulation during greening in normal and tumor tissues of Catharanthus roseus. J Plant Physiol 140:213-217

Luijendijk T (1995) Strictosidine glucosidase in indole alkaloid producing plants; characteristics and physiological implications. PhD thesis, Leiden University, The Netherlands

Luijendijk T, Stevens LH, Verpoorte R (1998) Purification and characterization of strictosidine $\beta$-D-glucosidase from Catharanthus roseus cell suspension cultures. Plant Physiol Biochem 36:419-425

Madyastha KM, Coscia CJ (1979) Enzymology of indole alkaloid biosynthesis. Recent Adv Phytochem 13:85129

Madyastha KM, Guarnaccia R, Baxter C, Coscia CJ (1973) Monoterpene biosynthesis VII: $S$-adenosyl-L-methionine: loganic acid methyltransferase, a carboxyl-alkylating enzyme from Vinca rosea. J Biol Chem 248:2497-2501

Madyastha KM, Meehan TD, Coscia CJ (1976) Characterization of a cytochrome P-450 dependent monoterpene hydroxylase from the higher plant Vinca rosea. Biochemistry 15:1097-1102

Madyastha KM, Ridgway JE, Dwyer JG, Coscia CJ (1977) Subcellular localization of a cytochrome P-450 monooxygenase in vesicles of the higher plant Catharanthus roseus. J Cell Biol 72:302-313

Maldonada-Mendosa IE, Burnett RJ, Nessler CL (1992) Nucleotide sequence of a cDNA encoding 3-hydroxy3-methylglutaryl-coenzyme A reductase from Catharanthus roseus. Plant Physiol 100:1613-1614

Maldonada-Mendosa IE, Burnett RJ, Lopez-Meyer M, Nessler CL (1994) Regulation of 3-hydroxy-3-methylglutaryl-coenzyme A reductase by wounding and methyljasmonate. Plant Cell Tissue Organ Cult 38:351-356

Mangold U, Eichel J, Batschauer A, Lanz T, Kaiser T, Spangenberg G, Werck-Reichhart D, Schröder J (1994) Gene and cDNA for plant cytochrome p450 proteins (CYP72 family) from Catharanthus roseus, and transgenic expression of the gene and a cDNA in tobacco and Arabidopsis thaliana. Plant Sci 96:129136

McFarlane J, Madyastha KM, Coscia CJ (1975) Regulation of secondary metabolism in higher plants. Effect of alkaloids on a cytochrome p450 dependent monooxygenase. Biochem Biophys Res Commun 66:1263-1269

McKaskill D, Croteau R (1995) Monoterpene and sesquiterpene biosynthesis in glandular trichomes of peppermint (Mentha $\times$ piperita) rely exclusively on plastid-derived iospentenyl diphosphate. Planta 197:49-56

McKnight TD, Roessner CA, Devagupta R, Scott AI, Nessler CL (1990) Nucleotide sequence of a cDNA encoding the vacuolar protein strictosidine synthase from Catharanthus roseus. Nucleic Acids Res 18:4939

McKnight TD, Bergey DR, Burnett RJ, Nessler CL (1991) Expression of enzymatically active and correctly targeted strictosidine synthase in transgenic tobacco plants. Planta 185:148-152

Mehdy MC (1994) Active oxygen species in plant defense against pathogens. Plant Physiol 105:467-472

Meijer AH, de Waal A, Verpoorte R (1993a) Purification of the cytochrome P-450 enzyme geraniol 10-hydroxylase from cell cultures of Catharanthus roseus. J Chromatogr 635:237-249

Meijer AH, Lopes Cardoso MI, Voskuilen JT, de Waal A, Verpoorte R, Hoge JHC (1993b) Isolation and characterization of a cDNA clone from Catharanthus roseus encoding NADPH: cytochrome $\mathrm{P} 450$ reductase, an enzyme essential for reactions catalyzed by cytochrome P450 mono-oxygenases in plants. Plant J 4:47-60

Memelink J, Verpoorte R, Kijne JW (2001) ORCAnisation of jasmonate-responsive gene expression in alkaloid metabolism. Trends Plant Sci 6:212-219

Menke FLH, Champion A, Kijne JW, Memelink J (1999) A novel jasmonate- and elicitor-responsive element in the periwinkle secondary metabolite biosynthetic gene str interacts with a jasmonate- and elicitorinducible AP2-domain transcription factor, ORCA2. EMBO J 18:4455-4463

Merillon JM, Doireau P, Guillot A, Chenieux JC, Rideau M (1986) Indole alkaloid accumulation and tryptophan decarboxylase activity in Catharanthus roseus cells cultures in three different media. Plant Cell Rep 5:23-26

Mizukami H, Nördlov H, Lee SI, Scott AI (1979) Purification and characterization of strictosidine synthase (an enzyme condensing tryptamine and secologanin) from Catharanthus roseus cultured cells. Biochemistry 18:3760-3763

Mizutani M, Ward E, Ohta D (1998) Cytochrome P450 superfamily in Arabidopsis thaliana: isolation of cDNAs, differential expression and RFLP mapping of multiple cytochrome P450. Plant Mol Biol 37:39-52

Montamat F, Guilloton M, Karst F, Delrot S (1995) Isolation and characterization of a cDNA encoding 
Arabidopsis thaliana 3-hydroxy-3-methylglutarylcoenzyme A synthase. Gene 167:197-201

Moreno PRH, van der Heijden R, Verpoorte R (1993) Effect of terpenoid precursor feeding and elicitation on formation of indole alkaloids in cell suspension cultures of Catharanthus roseus. Plant Cell Rep 12:702-705

Moreno PRH, van der Heijden R, Verpoorte R (1995) Cell and tissue cultures of Catharanthus roseus: a literature survey. II. Updating from 1988 to 1993. Plant Cell Tissue Organ Cult 42:1-25

Moreno PRH, Poulsen C, van der Heijden R, Verpoorte R (1996) Effects of elicitation on different secondary metabolic pathways in Catharanthus roseus cell suspension cultures. Enzyme Microb Technol 18:99-107

Morgan JA, Shanks JV (1999) Inhibitor studies of tabersonine metabolism in $C$. roseus hairy roots. Phytochemistry 51:61-68

Morgan JA, Shanks JV (2000) Determination of metabolic rate-limitations by precursor feeding in Catharanthus roseus hairy root cultures. J Biotechnol 79:137-145

Murata J, De Luca V (2005) Localization of tabersonine 16-hydroxylase and 16-OH-tabersonine-16- $O$-methyltransferase to leaf epidermal cells defines them as a major site of precursor biosynthesis in the vindoline pathway in Catharanthus roseus. Plant J 44:581-594

Nebert DW (1979) Multiple forms of inducible drugmetabolizing enzymes: a reasonable mechanism by which any organism can cope with adversity. Mol Cell Biochem 27:27

Newman JD, Chappell J (1999) Isoprenoid biosynthesis in plants: carbon partitioning within the cytoplasmic pathway. Crit Rev Biochem Mol Biol 34:95-106

Noe W, Berlin J (1984) Tryptophan decarboxylase from Catharanthus roseus cell suspension cultures: purification, molecular and kinetic data of the homogenous protein. Plant Mol Biol 3:281-288

Ouwerkerk PBF, Memelink J (1999) Elicitor-responsive promoter regions in the tryptophan decarboxylase gene from Catharanthus roseus. Plant Mol Biol 39:129-136

Pasquali G (1994) Regulation of the terpenoid indole alkaloid biosynthetic gene strictosidine synthase from Catharanthus roseus. $\mathrm{PhD}$ thesis, Leiden University

Pasquali G, Goddijn OJM, De Waal A, Verpoorte R, Schilperoort RA, Hoge JHC, Memelink J (1992) Coordinated regulation of two indole alkaloid biosynthesis genes from Catharanthus roseus by auxin and elicitors. Plant Mol Biol 18:1121-1131

Pennings EJ, Groen B, Duine JA, Verpoorte R (1989a) Tryptophan decarboxylase from Catharanthus roseus is a pyridoxo-quinoprotein. FEBS Lett 255:97-100

Pennings EJ, Verpoorte R, Goddijn OJM, Hoge JHC (1989b) Purification of tryptophan decarboxylase from cell cultures of Catharanthus roseus. J Chromatogr 483:311-318

Pennings EJ, van den Bosch RA, van der Heiden R, Stevens LH, Duine JA, Verpoorte R (1989c) Assay of strictosidine synthase from plant cell cultures by highperformance liquid chromatography. Anal Biochem 176:412-415
Piñas A, Ahumada J, Gonzalez V, Vollack KU, Bach TJ, Boronat A (1997) Cloning and characterization of cDNA clones encoding acetoacetyl-CoA thiolase from Arabidopsis thaliana. In: Abstract book, 3rd Terpnet meeting, Université de Poitier, France, May 29-30

Poulsen C, Verpoorte R (1991) Roles of chorismate mutase, isochorismate synthase and anthranilate synthase in plants. Phytochemistry 30:377-386

Poulsen C, Bongaerts R, Verpoorte R (1993) Purification and characterization of anthranilate synthase from Catharanthus roseus. Eur J Biochem 212:431-440

Power R, Kurz WGW, De Luca V (1990) Purification and characterization of acetylcoenzyme A: deacetylvindoline 4-O-acetyltransferase from Catharanthus roseus. Arch Biochem Biophys 279:370-376

Radman R, Saez T, Bucke C, Keshavarz T (2003) Elicitation of plants and microbial cell systems. Biotechnol Appl Biochem 37:91-102

Ramos-Valdivia AC, van der Heijden R, Verpoorte R (1997) Isopentenyl diphosphate isomerase: a core enzyme in isoprenoid biosynthesis. A review of its biochemistry and function. Nat Prod Rep 14:591603

Ramos-Valdivia AC, van der Heijden R, Verpoorte R (1998) Isopentenyl diphosphate isomerase and prenyltransferase activities in rubiaceous and apocynaceous cultures. Phytochemistry 48:961-969

Reymond P, Farmer E (1998) Jasmonate and salicylate as global signals for defense gene expression. Curr Opin Plant Biol 1:404-411

Rijhwani SK, Shanks JV (1998) Effect of elicitor dosage and exposure time on biosynthesis of indole alkaloids by Catharanthus roseus hairy root cultures. Biotechnol Prog 14:442-449

Rodriguez-Concepcion M, Boronat A (2002) Elucidation of the methylerythritol phosphate pathway for isoprenoid biosynthesis in bacteria and plastids. A metabolic milestone achieved through genomics. Plant Physiol 130:1079-1089

Rohdich F, Wungsintaweekul J, Luttgen H, Fischer M, Eisenreich W, Schuhr CA, Fellermeier M, Schramek N, Zenk M, Bacher A (2000) Biosynthesis of terpenoids: 4-diphosphocytidyl-2- $C$-methyl-D-erythritol kinase from tomato. Proc Natl Acad Sci USA 97:8251-8256

Rohdich F, Kis K, Bacher A, Eisenreich W (2001) The non-mevalonate pathway of isoprenoids: genes, enzymes and intermediates. Curr Opin Chem Biol 5:535-540

Rohmer M (1999) The discovery of a mevalonate-independent pathway for isoprenoid biosynthesis in bacteria, algae and higher plants. Nat Prod Rep 16:565-574

Rüffer M, Kan-Fan C, Husson HP, Stöchigt J, Zenk MH (1979) 4,1-Dehydrogeissoschizine, an intermediate in heteroyohimbine alkaloid biosynthesis. J Chem Soc Chem Commun 1016-1018

Sagner S, Eisenreich W, Fellermeier M, Latzel C, Bacher A, Zenk MH (1998) Biosynthesis of 2- $C$-methyl-Derythritol in plants by rearrangement of the terpenoid 
precursor 1-deoxy-D-xylulose 5-phosphate. Tetrahedron Lett 39:2091-2094

Schiel O, Witte L, Berlin J (1987) Geraniol-10-hydroxylase activity and its relation to monoterpene indole alkaloid accumulation in cell suspension cultures of Catharanthus roseus. Z Naturforsch 42c:1075-1081

Scheel D (1998) Resistance response physiology and signal transduction. Curr Opin Plant Biol 1(4):305-310

Schröder G, Unterbusch E, Kaltenbach M, Schmidt J, Strack D, De Luca V, Schröder J (1999) Lightinduced cytochrome P450-dependent enzyme in indole alkaloid biosynthesis: tabersonine 16-hydroxylase. FEBS Lett 458:97-102

Schulte AE (1998) Regulation of mevalonate metabolism in Catharanthus roseus. PhD thesis, Leiden University, The Netherlands

Schulte AE, van der Heijden R, Verpoorte R (1999) Purification and characterization of phosphomevalonate kinase from Catharanthus roseus. Phytochemistry 52:975-983

Schulte AE, van der Heijden R, Verpoorte R (2000) Purification and characterization of mevalonate kinase from Catharanthus roseus (L.) G. Don. Arch Biochem Biophys 378:287-298

Schwender J, Müller C, Zeidler J, Lichtenthaler HK (1999) Cloning and heterologous expression of a cDNA encoding 1-deoxy-D-xylulose 5-phosphate reductoisomerase of Arabidopsis thaliana. FEBS Lett 455:140-144

Scott AI, Lee SL, Wan W (1977) Indole alkaloid biosynthesis: partial purification of ajmalicine synthase from Catharanthus roseus. Biochem Biophys Res Commun 75:1004-1009

Shanks JV, Bhadra R (1997) Characteristics of selected hairy root lines of Catharanthus roseus. In: Doran PM (ed) Hairy roots. Harwood, Reading, UK, pp $51-63$

Sierra M (1991) Aspects of indole alkaloid accumulation in Tabernaemontana tissue cultures: differentiation, peroxidases and stability. $\mathrm{PhD}$ thesis, Leiden University, The Netherlands

Smith JI, Smart NJ, Kurz WGW, Misawa M (1987) Stimulation of indole alkaloid production in cell suspension cultures of Catharanthus roseus by abscisic acid. Planta Med 53:470-474

Sommer S, Severin K, Camara B, Heide L (1995) Intracellular localization of geranylpyrophosphate synthase from cell cultures of Lithospermum erythrorhizon. Phytochemistry 38:623-627

Sottomayor M, de Pinto MC, Salema R, DiCosmo F, Pedreno MA, Ros Barcelo A (1996) The vacuolar localization of a basic peroxidase isoenzyme responsible for the synthesis of $\alpha-3^{\prime}, 4^{\prime}$-anhydrovinblastine in Catharanthus roseus (L.) G. Don leaves. Plant Cell Environ 19:761-767

Sottomayor M, Lopez-Serrano M, DiCosmo F, RosBarcelo A (1998) Purification and characterization of alpha-3', 4'-anhydrovinblastine synthase (peroxidase-like) from Catharanthus roseus (L.) G. Don. FEBS Lett 428:299-303
Sprenger GA (1996) Carbohydrate metabolism in Zymomonas mobilis: a catabolic highway with some scenic routes. FEMS Microbiol Lett 145:301-307

Sprenger GA, Schorken U, Wiegert T, Grolle S, de Graaf AA, Taylor SV, Begley TP, Bringer-Meyer S, Sahm H (1997) Identification of a thiamin-dependent synthase in Escherichia coli required for the formation of the 1-deoxy-D-xylulose. Proc Natl Acad Sci USA 94:12857-12862

St-Pierre B, De Luca V (1995) A cytochrome P-450 monooxygenase catalyzes the first step in the conversion of tabersonine to vindoline in Catharanthus roseus. Plant Physiol 109:131-139

St-Pierre B, Laflamme P, Alarco AM, De Luca V (1998) The terminal $O$-acetyltransferase involved in vindoline biosynthesis defines a new class of proteins responsible for coenzyme A-dependent acyl transfer. Plant J 14:703-713

St-Pierre B, Vazquez-Flota FA, De Luca V (1999) Multicellular compartmentation of Catharanthus roseus alkaloid biosynthesis predicts intercellular translocation of a pathway intermediate. Plant Cell 11:887900

Stermer BA, Bianchini GM, Korth KL (1994) Regulation of HMG-CoA reductase activity in plants: review. J Lipid Res 35:1133-1140

Stevens LH (1994) Formation and conversion of strictosidine in the biosynthesis of monoterpenoid indole and quinoline alkaloids. PhD thesis, Leiden University, The Netherlands

Stevens LH, Blom TJM, Verpoorte R (1993) Subcellular localization of tryptophan decarboxylase, strictosidine synthase and strictosidine $\beta$-D-glucosidase in suspension cultured cells of Catharanthus roseus and Tabernaemontana divaricata. Plant Cell Rep 12:573-576

Stöckigt J (1980) In: Phillipson JD, Zenk MH (eds) Indole and biogenetically related alkaloids. Academic, London, p 113

Takahashi S, Kuzuyama T, Watanabe H, Seto H (1998) A 1-deoxy-D-xylulose 5-phosphate reductoisomerase catalyzing the formation of 2-C-methyl-D-erythritol 4-phosphate in an alternative nonmevalonate pathway for terpenoid biosynthesis. Proc Natl Acad Sci USA 95:9879-9884

Treimer JF, Zenk MH (1979) Purification and properties of strictosidine synthase, the key enzyme in indole alkaloid formation. Eur J Biochem 101:225-233

Uesato S, Ogawa Y, Inouye H, Saiki K, Zenk MH (1986) Synthesis of iridodial by cell free extracts from Rauwolfia serpentina cell suspension cultures. Tetrahedron Lett 27:2893-2896

Uesato S, Ikeda H, Fujita T, Inouye H, Zenk MH (1987) Elucidation of iridodial formation mechanism-partial purification and characterization of the novel monoterpene cyclase from Rauwolfia serpentina cell suspension cultures. Tetrahedron Lett 28:4431-4434

Van der Fits L, Memelink J (2000) ORCA3, a jasmonateresponsive transcriptional regulator of plant primary and secondary metabolism. Science 289:295-297

Van der Fits L, Memelink J (2001) The jasmonateinducible AP2/ERF-domain transcription factor 
ORCA3 activates gene expression via interaction with a jasmonate-responsive promoter element. Plant $\mathrm{J}$ 25:43-53

Van der Heijden R, Verpoorte R (1995) Metabolic enzymes of 3-hydroxy-3-methylglutaryl-coenzyme A in Catharanthus roseus. Plant Cell Tissue Organ Cult 43:85-88

Van der Heijden R, Boer-Hlupa V, Verpoorte R, Duine JA (1994) Enzymes involved in the metabolism of 3-hydroxy-3-methylglutaryl-coenzyme A in Catharanthus roseus. Plant Cell Tissue Organ Cult 38:345-348

Vasquez-Flota FA, De Luca V (1998) Jasmonate modulates development- and light-regulated alkaloid biosynthesis in Catharanthus roseus. Phytochemistry 49:395-402

Vasquez-Flota FA, De Carolis ED, Alarco AM, De Luca V (1997) Molecular cloning and characterization of desacetoxyvindoline-4-hydroxylase, a 2-oxoglutarate dependent-dioxygenase involved in the biosynthesis of vindoline in Catharanthus roseus (L.) G. Don. Plant Mol Biol 34:935-948

Vasquez-Flota FA, St-Pierre B, De Luca V (2000) Light activation of vindoline biosynthesis does not require cytomorphogenesis in Catharanthus roseus seedlings. Phytochemistry 55:531-536

Veau B, Courtois M, Oudin A, Chenieux JC, Rideau M, Clastre M (2000) Cloning and expression of cDNAs encoding two enzymes of the MEP pathway in Catharanthus roseus. Biochem Biophys Acta 1517:159-163

Verpoorte R (1998) Exploration of nature's chemodiversity: the role of secondary metabolites as lead for drug development. Drug Dev Today 3:232-238

Verpoorte R, Alfermann AW (2000) Metabolic engineering of plant secondary metabolism. Kluwer Academic Publishers, Dordrecht

Verpoorte R, van der Heijden R, Moreno PRH (1997) Biosynthesis of terpenoid indole alkaloids in Catharanthus roseus cells. In: Cordell GA (ed) The alkaloids, vol 49. Academic, San Diego, pp 221-299

Verpoorte R, van der Heijden R, Memelink J (1998) Plant biotechnology and the production of alkaloids: prospects of metabolic engineering. In: Cordell GA (ed) The alkaloids, vol 50. Academic, San Diego, pp 453508

Verpoorte R, van der Heijden R, Memelink J (2000) Engineering the plant cell factory for secondary metabolite production. Transgenic Res 9:323-343

Verpoorte R, Contin A, Memelink J (2002) Biotechnology for the production of plant secondary metabolites. Phytochem Rev 1:13-25

Vetter HP, Mangold U, Schröder G, Marner FJ, WerckReichhart D, Schröder J (1992) Molecular analysis and heterologous expression of an inducible cytochrome $\mathrm{P} 450$ protein from periwinkle (Catharanthus roseus L.). Plant Physiol 100:998-1007

Vollack KU, Bach TJ (1995) In: Kader JC, Mazliak P (eds) Plant lipid metabolism. Kluwer Academic Publishers, Dordrecht, p 335

Weber T, Bach TJ (1994) Conversion of acetyl-coenzyme A into 3-hydroxy-3-methylglutaryl-coenzyme $\mathrm{A}$ in radish seedlings; evidence of a single monomeric protein catalyzing a FeII/quinone-stimulated double condensation reaction. Biochim Biophys Acta 1211:85-96

Weissenborn DL, Denbow CJ, Laine M, Lang SS, Yang Z, Yu X, Cramer CL (1995) HMG-CoA reductase and terpenoid phytoalexines: molecular specialization within a complex pathway. Physiol Plant 93:393400

Whitmer S (1999) Aspects of terpenoid indole alkaloid formation by transgenic cell lines of Catharanthus roseus over-expressing tryptophan decarboxylase and strictosidine synthase. $\mathrm{PhD}$ thesis, Leiden University

Whitmer S, Canel C, Hallard D, Goncalves C, Verpoorte $R$ (1998) Influence of precursor availability on alkaloid accumulation by transgenic cell line of Catharanthus roseus. Plant Physiol 116:853-857

Whitmer S, van der Heijden R, Verpoorte R (2002a) Effect of precursor feeding on alkaloid accumulation by a strictosidine synthase over-expressing transgenic cell line S1 of Catharanthus roseus. Plant Cell Tissue Organ Cult 69:85-93

Whitmer S, van der Heijden R, Verpoorte R (2002b) Effect of precursor feeding on alkaloid accumulation by a tryptophan decarboxylase overexpressing transgenic cell line T22 of Catharanthus roseus. J Biotechnol 96:193-203

Yahia A, Kevers C, Gaspar T, Chènieux J, Rideau M, Crèche J (1998) Cytokinins and ethylene stimulate indole alkaloid accumulation in cell suspension cultures of Catharanthus roseus by two distinct mechanisms. Plant Sci 133:9-15

Yamamoto H, Katano N, Ooi A, Inoue K (2000) Secologanin synthase which catalyzes the oxidative cleavage of loganin into secologanin is a cytochrome P450. Phytochemistry 53:7-12

Zhao J, Zhu W, Hu Q, He XW (2000a) Improved indole alkaloid production in Catharanthus roseus suspension cultures by various chemicals. Biotechnol Lett 22:1221-1226

Zhao J, Zhu W, Hu Q (2000b) Promotion of indole alkaloid production in Catharanthus roseus cell cultures by rare earth elements. Biotechnol Lett 22:825-828

Zhao J, Zhu W, Hu Q (2001a) Effects of light and plant growth regulators on the biosynthesis of vindoline and other indole alkaloids in Catharanthus roseus callus cultures. Plant Growth Regul 33:43-49

Zhao J, Zhu W, Hu Q (2001b) Enhanced catharanthine production in catharanthus roseus cell cultures by combined elicitor treatment in shake flasks and bioreactors. Enzyme Microb Technol. May 7; 28(7-8):673-681

Zhao J, Zhu W, Hu Q (2001c) Selection of fungal elicitors to increase indole alkaloid accumulation in catharanthus roseus suspension cell culture. Enzyme Microb Technol. May 7; 28(7-8):666-672

Zheng Z, Wu M (2004) Cadmium treatment enhances the production of alkaloid secondary metabolites in Catharanthus roseus. Plant Sci 166:507-514 